\title{
Hot and cold IPO markets : the case of the stock exchange of Mauritius
}

Article

Accepted Version

Subadar Agathee, U., Brooks, C. and Sannassee, R. V. (2012) Hot and cold IPO markets : the case of the stock exchange of Mauritius. Journal of Multinational Financial Management, 22 (4). pp. 168-192. ISSN 1042-444X doi:

https://doi.org/10.1016/j.mulfin.2012.06.004 Available at https://centaur.reading.ac.uk/36096/

It is advisable to refer to the publisher's version if you intend to cite from the work. See Guidance on citing.

Published version at: http://dx.doi.org/10.1016/j.mulfin.2012.06.004

To link to this article DOI: http://dx.doi.org/10.1016/j.mulfin.2012.06.004

Publisher: Elsevier

All outputs in CentAUR are protected by Intellectual Property Rights law, including copyright law. Copyright and IPR is retained by the creators or other copyright holders. Terms and conditions for use of this material are defined in the End User Agreement.

\section{www.reading.ac.uk/centaur}

\section{CentAUR}

Central Archive at the University of Reading 
Reading's research outputs online 
NOTICE: this is the author's version of a work that was accepted for publication in the Journal of Multinational Financial Management. Changes resulting from the publishing process, such as peer review, editing, corrections, structural formatting, and other quality control mechanisms may not be reflected in this document. Changes may have been made to this work since it was submitted for publication. A definitive version was subsequently published in the Journal of Multinational Financial Management, 22.4 (2012) DOI: 10.1016/j.mulfin.2012.06.004 


\title{
Hot and Cold IPO Markets: \\ The case of the Stock Exchange of Mauritius
}

\author{
Ushad Subadar Agathee \\ Department of Finance and Accounting, \\ Faculty of Law and Management, \\ University of Mauritius. \\ Email: u.subadar@uom.ac.mu \\ Chris Brooks* \\ ICMA Centre \\ University Of Reading \\ Email: c.brooks@ icmacentre.reading.ac.uk \\ Raja Vinesh Sannassee \\ Department of Finance and Accounting, \\ Faculty of Law and Management, \\ University of Mauritius. \\ Email: rvsan@uom.ac.mu
}

\begin{abstract}
The aim of this study is to assess the characteristics of the hot and cold IPO markets on the Stock Exchange of Mauritius. The results show that the hot issues exhibit, on average, a greater degree of underpricing than the cold issues, although the hot issue phenomenon is not a significant driving force in explaining this short-run underpricing. The results are consistent with the predictions of the changing risk composition hypothesis in suggesting that firms going public during hot markets are on average relatively more risky. The findings also support the time adverse selection hypothesis in that the firms' quality dispersion is statistically different between hot and cold markets. Finally, the study concludes that firms which go public during hot markets do not underperform those going public in cold markets over the longer term.
\end{abstract}

Keywords: Initial Public Offerings, Underpricing; Hot/ Cold issue markets; Changing Risk Composition Hypothesis; Stock Exchange of Mauritius; Mauritius

JEL classifications: G14, G32, O16 


\section{Introduction}

The decision to go public is an important stage in the growth process of any company and there are many different motives behind this decision. In effect, firms typically make unseasoned offers of new shares on the market mainly for the purpose of raising capital. Alternatively, existing shareholders may decide to sell their shares to the public in an attempt to cash in their investment. Thirdly, a firm may go public to enhance its reputation and visibility so that it can gain a vital competitive edge or be valued by other firms for a potential merger. Zingales (1995) argues that firms go public because entrepreneurs feel that they could obtain a higher price on the public market than from a private sale. In particular, it is easier for potential acquirers to spot the firm in public market. Chemmanur and Fulghieri (1999) argue that it becomes optimal to go public when firms grow large later in their lifecycle. They claim that IPOs lead to more dispersion of ownership. Lucas and McDonald (1990) suggest that firms will postpone their IPOs in bear markets and go public in bull markets to obtain a favourable pricing. According to Lucas and McDonald (1990), the market will place too low a value on the firms if they are bearish. In addition, industry-specific factors such as the arrival of innovation, and economic factors such as business cycles, are drivers of IPO volumes.

However, IPOs appear to occur in cycles in terms of their number and the extent to which the initial prices are too low (termed underpricing). There seem to exist periods of high IPO volume associated with high initial returns, which are termed hot issue periods. ${ }^{1}$ This cyclical behaviour creates possible distortions to the models of continuous efficient markets. Based on the studies of Ritter (1984), Ibbotson et al. (1994), Loughran and Ritter (1995) and Ghosh (2004), the time series behaviour of first day returns and IPO volume are linked. To this effect, the objective of this research is to identify and explain the hot issue phenomenon in the context of the Mauritian

\footnotetext{
${ }^{1}$ Ibbotson and Jaffe (1975).
} 
stock market. In particular, the study will initially consider the number of firms listed on the Stock Exchange of Mauritius (SEM) to infer any discernible clustering patterns of IPO activities.

Essentially, the newness of the Mauritian market, the relative lack of investor knowledge and the distinct institutional features make the SEM a unique environment in which to conduct research. In particular, very little research has been done with regards to IPOs in the African markets and the literature is not so abundant relative to that on developed markets such as the US and the UK. This may be explained by the fact that most stock exchanges in Africa are relatively young and indeed, most were set up in the early 1990's. To the authors' knowledge, there has not been any formal attempt to study the hot and cold issue markets on the SEM. In this respect, this paper aims to fill this research gap in the literature.

The SEM is truly a unique market as the IPO mechanisms in place differ compared with those in practice in other developed and developing markets. In particular, the role of the underwriter is limited as there are no investment banks in Mauritius and new issues are sponsored and marketed by stockbroking companies. In addition, the listing rules do not require as much information compared with that needed in developed or indeed many other developing markets. Studies on other markets have emphasised the key role that the underwriter has in the process, and therefore the present study represents a unique opportunity to evaluate the impact of its absence.

Moreover, it would be interesting whether or not the same hot issue markets' characteristics prevail in a small and thinly traded market. The US and UK stock markets that dominate empirical applications in this area are very large, highly liquid with turnover ratios well exceeding $100 \%$ each year. On the other hand, the SEM's capitalisation is less than one percent of that of the UK or US, and its turnover ratio has never been greater than $10 \%$ over the period since 1989. It is thus of interest to ascertain whether the key theories that have been developed to 
explain the patters of IPO pricing in hot and cold developed markets also apply in the context of this small island economy.

\section{Prior Research}

An examination of the relevant literature reveals a cyclical pattern of average initial returns over time. Ibbotson and Jaffe (1975) initially documented this cyclical pattern, suggesting the existence of the "hot issue market". The recurring pattern of average initial returns, based on Ibbotson et al. (1988), is associated with an increasing volume of IPOs. Essentially, periods of unusually high initial returns associated with a high volume of IPOs, are coined 'hot issue' periods. However, a cold issue market will typically develop at the end of the hot issue period where unusually low initial returns will tend to occur. Ritter (1984) reports unusually high average initial returns of $48.4 \%$ for the period $1980-81$ in the US market relative to the average return of $16.3 \%$ over the period 1977-82. Ibbotson et al. (1988) confirm this recurring pattern of initial returns when they extend the sample period. Apart from the cyclical swings in initial returns, various studies ${ }^{2}$ have also claimed a lead-lag relationship between IPO volumes and underpricing, suggesting that firms judiciously time their IPOs. In this respect, Baker and Wurgler (2000) argue that firms on average issue comparatively more equity than debt prior to periods of low market returns, indicating timing ability, while Ljungqvist and Wilhelm (2003) claim that there was an increase in the yearly mean and median issue size among US IPOs for the period between 1996 and 2000 as the IPO market became 'hotter'.

Theoretically, the issuer's aim is to maximise issue proceeds and leave the minimum amount of money on the table. Therefore, a firm will normally go public in periods of low initial returns. However, the empirically observed positive relationship between underpricing and IPO volume is a puzzling phenomenon. While there are no unanimously supported explanations of this empirical

\footnotetext{
${ }^{2}$ For example, Ibbotson and Jaffe (1975), Ritter (1984), Ibbotson, Sindelar and Ritter (1988, 1994), and Lowry and Schwert (2002).
} 
anomaly, the section below suggests different possible reasons described in the literature for the clustering of IPOs and the degree of underpricing over time.

\subsection{The Changing Risk-Composition Hypothesis}

According to Ritter (1984), the observed hot issue phenomenon may be due to the changing risk composition of the IPO market. He claims that riskier issues tend to be underpriced heavily and that the hot issue period may reflect the period where more risky firms go public. Ritter (1984) uses Rock's (1982) model to argue that riskier firms are difficult to value and as such, uninformed investors will be more uncertain of the aftermarket price. Hence, riskier firms will have higher average initial returns. In particular, based on Rock's model, Ritter (1984) states that "if there is autocorrelation in the risk composition of firms conducting initial public offerings, then the realised average returns should be autocorrelated." Based on the above explanations, a positive relationship between not only risk and initial returns but also between risk and the variability of initial returns ${ }^{3}$ is implied. As such, if a large proportion of firms going public in a particular period are risky, the average initial returns will be higher such that a 'hot-issue' period will occur. Ritter (1984) segregates firms according to their risk classes to examine the positive relationship between average initial returns and risk before evaluating whether the dynamic risk composition can explain the hot markets. Using annual sales as a proxy for risk, Ritter (1984) finds that higher risk firms exhibit higher average initial returns and higher variation in initial returns. However, based on further analysis, He finds that the hot issue phenomenon appears only for natural resource issues and is not clearly visible for non-natural resource IPOs. In general, Ritter (1984) claims that the hot issue phenomenon may be the result of firms from high-risk industries entering the market, thereby leading to higher initial returns.

\footnotetext{
${ }^{3}$ Due to the uncertainty of initial returns for riskier issues.
} 
Different studies ${ }^{4}$ have focused on firm characteristics such as age, sales, assets, industry, and underwriter prestige to test the changing composition of IPOs over time, in particular during the hot and cold periods. According to Loughran and Ritter (2004), using a sample of US IPOs from 1980-2003, firm characteristics fail to account for the unusual trend in average initial returns. Similarly, Helwege and Liang (2004) report that firm characteristics are more or less similar in hot and cold markets. However, some authors including Lowry and Schwert (2002), Fink et al. (2005) and Howe and Zhang (2005), argue that various firm characteristics such as firm age and underwriter quality can explain the cyclical patterns of IPOs. However, as reported by Yung et al. (2008), "these studies do not address the underlying causes of observed variation in firm characteristics." In other words, these studies attempt to relate firm characteristics to the patterns of IPOs but do not explain why firm characteristics will change over time or over specific periods.

\subsection{The Market Timing and Investor Sentiment Hypothesis}

Empirically, the IPO literature has listed investors' optimism as one of the driving forces for the cyclical rise in initial returns. Undoubtedly, the long-run underperformance of small and young IPOs during hot issue periods ${ }^{5}$ confirms that investors were initially overly enthusiastic. An accepted justification for poor IPO performance in "hot" IPO markets is market timing, where Baker and Wurgler (2000) claim that firms "time" their IPOs to coincide with periods of excessive valuations. Brau and Fawcett (2006) argue for market timing not only for IPOs but also for seasoned equity offerings (SEOs). Ljungqvist, Nanda and Singh (2005) predict that as the optimism of sentiment investors increases, more companies have an incentive to go public such that offer sizes will increase. Consistent with this finding, Lee, Shleifer, and Thaler (1991) argue

\footnotetext{
${ }^{4}$ Ritter (1984), Lowry and Schwert (2002), Helwege and Liang (2004), Fink et al. (2005), and Howe and Zhang (2005) amongst others.

${ }^{5}$ From the studies of Ritter (1991), Jain and Kini (1994), Ibbotson, Sindelar and Ritter (1988 and 1994), Lowry and Schwert (2002), and Helwege and Liang, (2001).
} 
that more companies go public when investor sentiment is high. Essentially, the impact of investor sentiment is regarded as particularly sensitive in hot markets.

\subsection{Market Timing and Long-run Underperformance}

If investors are irrationally optimistic, many firms will go public in times of high stock market valuation. However, based on the concept of market efficiency, this initial overreaction of investors will be reflected in long-run underperformance. For instance, Dorn (2002) investigates IPO trading on the German market and finds that high initial returns are followed by subsequent underperformance as retail investors reversed their initial purchases. In general, the period of relatively high IPO volume in times of investors' optimism combining with long-run underperformance favours evidence for market timing. Indeed, various studies ${ }^{6}$ have justified the long run underperformance of IPOs, arguing that managers take advantage of investors' optimism. Among the pioneering studies, Ritter (1991) finds evidence of "windows of opportunity," where managers can identify periods of overvaluation in the market such that there is a clustering of IPOs at market peaks. However, according to Löffler (2000), the ability to identify and predict periods of market overvaluation by managers is questionable. Indeed, IPO activities will be a good indication of future returns if managers have the necessary skills to forecast market overvaluation. Consistent with this view, Loughran, Ritter and Rydqvist (1994) find that IPO activity could not predict future returns in different markets. However, Baker and Wurgler (2000) find some evidence for the usefulness of IPO activity in predicting future returns in the US market.

\footnotetext{
${ }^{6}$ For example, Loughran and Ritter (1995), Rajan and Servaes (1997), Field (1997), and Teoh, Welch and Wong (1998).
} 


\subsection{The Sequential Learning, Informational Externality and Industry Concentration}

\section{Hypothesis and the Demand for Capital Hypothesis}

IPOs waves tend to be clustered around similar industries. ${ }^{7}$ According to Jenkinson and Ljungqvist (2001), recent IPO waves (in the late 1990s and early 2000s) were the result of technology-related new equity issues, both in the US and European markets. In particular, some studies $^{8}$ claim that it is more probable that a bunch of similar firms goes public as there is an information spill-over effect from observing earlier IPOs to subsequent IPOs. All the relevant stakeholders - namely issuers, investment bankers and investors, participate in the sequential learning process caused by information spill-overs. In other words, issuers of and investors in subsequent IPOs condition their behaviour based on the information externality created by the outcomes of previous IPOs. In general, issuers and investors will observe the outcomes of firms in similar industries, which are more informative than for firms in different industries, leading to industry clustering. In effect, according to Lowry and Schwert (2002), the overlapping of registration periods for many IPOs and the similarities in the types of IPOs will lead to serial correlation in initial returns. In addition, a high initial return will convey favourable information regarding the market's valuation. Following the positive information learned during the registration periods, more companies that are private will file for an IPO. Thus there should be a positive relationship between initial returns and the number of subsequent filings. Overall, the above explanations primarily lend support to the fact that IPOs cluster in time because of the externality of information for firms in similar industries and the sequential learning process.

The demand for capital hypothesis similarly argues that firms will time their IPOs to take place when the market is performing well simply so that the resulting costs of capital will be lower see Lucas and McDonald (1990) and Pastor and Veronesi (2005).

\footnotetext{
${ }^{7}$ According to Pagano, et al. (1998) and Jain and Kini (2006).

${ }^{8}$ Persons and Warther (1997), Subrahmanyam and Titman (1999), Hoffmann-Burchardi (2001), Benveniste et al. (2002) and Alti (2005).
} 


\subsection{The Asymmetric Information and Signalling Hypothesis}

Signalling theory asserts that high-quality companies will go public during a hot market and underprice more to signal their qualities and to win the confidence of investors. In this respect, Stoughton, Wong and Zechner (2001) develop a model of IPO decisions based on product quality. In particular, a firm will go public because of certain information being conveyed to the stock market, which is thereby translated in the product market as a signal of product quality. When firms go public, customers or investors perceive that those firms willingly offer themselves for external scrutiny. As such, customers infer high product quality from stock prices which will react favourably to customers' perceptions. Stoughton et al. (2001) predict that the IPO process will be more viable to signal the quality of the firm than through the price mechanism since similar firms in particular industries will tend to have small differences in marginal costs of production. In addition, if a firm goes public, it will provide better information about the industry's prospects. In this case, their model implies a clustering of firms in the same industry because of informational effects.

\subsection{Asymmetric Information and the Time Varying Adverse Selection Hypothesis}

Lowry (2003) develops the information asymmetry hypothesis to state the time-varying uncertainty surrounding the value of firms and its impact on IPO volume. Typically, there is a disparity between issuers' information and market perceptions of firm value. This information asymmetry creates an adverse selection cost whereby the market will tend to undervalue firms when they announce their offerings because of the managers' incentives to issue equity when their firms are overvalued. The higher the information asymmetry, the higher the adverse selection costs and therefore, the higher will be the costs of issue to the firm. As such, firms will find it less optimal to issue equity and will choose other modes of financing. Following this rationale, Lowry (2003) predicts a negative relationship between IPO volume and information 
asymmetry. This result is inconsistent with Yung et al. (2008), who predict an increase in IPO volume with greater adverse selection. Overall, the time-varying adverse selection costs hypothesis focuses on the fluctuations of adverse selection costs over time for a particular firm such that issuers find it optimal to time their IPOs during some specific periods.

\section{An Overview of the Stock Exchange of Mauritius (SEM)}

The economic take-off in the early 1980's and the economic boom later that decade created a dynamic financial sector in Mauritius. To cater for the needs of a growing economy at that time, there was a consensus among leading economic operators of the need to broaden the Mauritian financial sector. In this context, the Stock Exchange Act 1988 was enacted to provide for the setting up of a Stock Exchange Commission (SEC), a regulatory body, as well as the Stock Exchange of Mauritius Ltd (SEM), a private company, established to operate and maintain the stock exchange. The SEMDEX, ${ }^{9}$ a market-weighted index, embodies the price movements of all companies listed on the official market. The official market of the Stock Exchange has categorised the companies listed into seven sectors - namely, Banks and Insurance, Industry, Investments, Sugar, Commerce, Leisure \& Hotels and Transport.

Currently, the market indices on the official market of the SEM are the SEMDEX, SEM-7 and the SEMTRI. The SEM-7 is a relatively new index, which has been operational since March 1998, comprising the shares of the seven largest eligible companies measured in terms of market capitalization, liquidity and investibility while the SEMTRI captures the gross dividends as well as the capital gains or losses of all stocks listed on the official market and is thus a total return index. The evolution of SEMDEX, SEM-7 and SEMTRI as well as the number of firms listed on the official market are shown in Figure 1. The SEM set up the three main market indices with

\footnotetext{
${ }^{9}$ The SEMDEX is an all shares index. It reflects capitalisation based on each listed stock which is weighted according to its shares in the overall market. The current value of the SEMDEX is expressed in relation to a base period, 5 July 1989, with a value of 100 .
} 
different objectives; however, when considering their performance, one can observe that the market indices are strongly linked. In effect, the SEMTRI closely tracks the movements of the SEMDEX as its calculation is based on the SEMDEX, which is then adjusted for gross dividends. Furthermore, the SEM-7 moves in a similar way relative to the SEMDEX, as the SEM is a highly concentrated market, dominated by a few large firms.

The SEMDEX experienced a rising trend up to the year 1994, when a peak was attained. However, in 1995, there was a sharp drop although the number of listed firms continued to increase. One possible reason advanced by the SEM was that the market was not prepared to absorb such a sudden rise in the supply of shares such that there was a sharp decline in share prices. Added to this was some negative reaction to budgetary measures. However, the market recovered at the end of 1996 following new measures announced by the Minister of Finance. After that, it maintained an upward trend until 1998. Eventually, the SEMDEX took a downward turn, together with the market capitalisation. The main explanation advanced by the SEM was that the effects of drought in 1999, coupled with the depreciating Euro, had an adverse effect on the earnings of several listed firms. From 2001 until 2007, the SEMDEX continued to increase to reach its peak at end of 2007. This sharp increase was mainly due to the increase of foreign investors' participation in the SEM and the adoption of the automated trading system in 2001 to improve liquidity and enhance price efficiency. However, with the effects of the global financial crisis, the SEMDEX witnessed a sharp drop in 2008, although it did recover in 2009.

According to Loughran, Ritter and Rydvist (1994), there is a clear tendency for a high number of IPOs to be associated with market peaks. To this effect, when considering the number of firms listed on the SEM and the movements of the market, it is observed that there is a high number of IPOs for the periods 1989-1991 and 1993/1994, associated with an upward trend of the SEMDEX, as shown in Figure 1. In particular, there were 32 IPOs during these periods. One can 
infer these years as the "hot issue" periods as they constitute more than $70 \%$ of companies listing on the SEM, taking into account the whole sample period 1989 until 2009.

\subsection{The Stockbroker, the Underwriter and the Sponsor in the Primary Market in Mauritius}

Eleven stockbroking companies are currently operating on the stock exchange. The stockbrokers act as agents for the clients in buying and selling shares on their behalf in the secondary market. In the primary market, stockbroking companies in Mauritius can act as the underwriter of the share offer or be the sponsoring broker. In certain circumstances, although it is very uncommon, stockbroking companies can be both the underwriter and the sponsor of the offer.

In particular, the role of the underwriter in the Mauritian context is simply to guarantee to take over any unsubscribed offer of the shares in case there is under-subscription. However, in contrast to the practice of some developed markets, it is not common for the underwriter to buy the shares directly from the issuer and sell them at a premium on the secondary market. In general, the price setting of shares comes under the discretion of the issuer.

The relevant listing rule does not provide a compulsory provision for the appointment of an underwriter. However, under section 4 of the listing rule, "an issuer must have a sponsor appointed at all times while it is an applicant or is listed". The sponsor must be an investment dealer or a financial institution which is registered with the SEM. In particular, the role of the sponsor is to certify that the issuer has met all conditions for listing to the best of his knowledge. In effect, the sponsor must undertake its own investigation and enquiry to ensure that the issuer is not in breach of any listing regulations. In this regard, the sponsor must provide a signed declaration that, to the best of its knowledge, the issuer is deemed 'fit' for listing. In general, it is stockbroking companies who act as sponsors when a company seeks admission to the exchange. The sponsoring stockbroker will act as an intermediary throughout the admission process and will 
ensure that the issuer is guided and advised as to the listing requirements and the post listing obligations of the company.

\section{Research Methodology}

The core objective of this research is to assess the existence of the hot issue phenomenon on the Stock Exchange of Mauritius. Essentially, periods of high initial returns are often related to an increasing number of IPOs. This phenomenon is dubbed the "hot issue market." 10 On the other hand, low initial returns are observed towards the end of hot issue periods ("cold issue markets"). Based on Ritter (1984), this observed phenomenon may be due to the changing risk composition of the IPO market. He claims that riskier issues tend to be underpriced heavily and that the hot issue period may be reflecting the time where more risky firms go public. As such, this study will attempt to identify and explain any clustering of high degrees of underpricing and IPOs through time on the Mauritian equity market.

\subsection{Sample and Data Collection Methods}

The data used in this study consist of all firms which have gone public on the official market of the Stock Exchange of Mauritius for the period 1989 until $2010 .^{11}$ Based on this criterion, the sample perfectly represents the population, consisting of 44 listed companies. ${ }^{12}$ Given the limited number of firms, we have included firms which have delisted during the sample period. ${ }^{13}$ The prospectuses as well as the annual reports were used to collect data prior to listing. In addition, daily price histories were obtained for each sample firm through the period 1989 to 2010 .

\footnotetext{
${ }^{10}$ See the studies from Ibbotson and Jaffe (1975), Ritter (1984), Ibbotson et al (1988), Baker and Wurgler (2000), Lowry and Schwert (2002), Ljungqvist and Wilhelm (2003), Helwege and Liang (2004), Fink et al. (2005), and Howe and Zhang (2005).

${ }^{11}$ Similar to the sample definition of Gasbarro et al. (2003).

${ }^{12}$ Our sample rffectively ends in 2005 since there were no Mauritian initial public offers of ordinary equities on the SEM from 2005 until 2010.

${ }^{13}$ There are seven firms which have delisted during the period 1989-2010. The SEM codes for these firms are CIT, COURTS,DELPHIS, GBH,LIT,MDA (O) and MOUNT.
} 
It is observed that the sample of firms is relatively small compared to studies on developed markets. However, Gasbarro et al. (2003) argue that the sample size is also relatively small in other emerging market IPO studies. For instance, Hameed and Lim (1998) and Omran (2005) both use a sample size of 53 firms to assess IPO anomalies on the Singaporean and Egyptian markets respectively. There are also other studies such as Procianoy and Cigerza (2007), Lyn and Zychowicz (2002), and Dawson (1987) who consider 29, 33 and 21 new issues on the Brazilian, Hungarian and Malaysian markets respectively.

\subsection{Underpricing Measurement}

There are a number of methods available to compute a measure of underpricing. For comparative purposes, the basic methodology followed in this paper is similar to those used in earlier studies. ${ }^{14}$ A simple, raw measure of underpricing is the first day initial return $\left(R_{i 1}\right)$ for each firm, which is calculated from the date of issue as:

$$
R_{i 1}=\left(P_{i 1} / P_{i 0}\right)-1
$$

where $P_{i 0}$ is the offer price of the firm $i, P_{i 1}$ is the first day closing price of share of the firm $i$ and $R_{i 1}$ is the total first day return on the stock.

If the markets are highly volatile such that there is a major and widespread price change during the IPO period, then initial returns should be market-adjusted. It is useful to note that the unadjusted returns are merely price differences and as such, do not take into account the comparable returns to an alternative investment. Various studies ${ }^{15}$ assume that the quoted market index is a comparable investment to calculate the first day adjusted initial returns. In particular, Lee (2003) argues that "the raw underpricing measure ... assumes all return is due to unique

\footnotetext{
${ }^{14}$ See the studies from McDonald and Fisher (1972), Aggarwal, Leal and Hernadez (1993), Affleck-Graves, Hegde and Miller (1996), Alvarez and Gonzalez (2001), and Gunther and Rummer (2006).

15 Aggarwal, Leal and Hernandez (1993), Levis (1993), Affleck-Graves, Hegde and Miller (1996), Ljungqvist (1997), and Alvarez and Gonzalez (2001).
} 
risks. However, this may overstate the return as market movements are a determinant of total return. Accordingly, adjustments for this source of variance are undertaken."

To compute the first day market adjusted return, the return of the market index is initially calculated as:

$$
R_{m 1}=\left(P_{m 1} / P_{m 0}\right)-1
$$

where $R_{m 1}$ is the one-day return for the market index (SEMDEX) corresponding to the offering by the firm $i, P_{m 1}$ is the closing value of the market index on the issue date corresponding to the offering by the firm $i$ and $P_{m 0}$ is the value of the market index corresponding to the offering price of the firm $i$.

The market adjusted return abnormal return for each IPO on the first trading day is therefore computed as:

$$
\operatorname{MAAR}_{i 1}=100 \times\left\{\left[\left(1+R_{i 1}\right) /\left(1+R_{m 1}\right)\right]-1\right\}
$$

where $M A A R_{i 1}$ is the one day excess return corresponding to the issue by firm $i, R_{i 1}$ is the one day return for firm $i$, and $R_{m 1}$ is the one day return for the market index corresponding to the offering by the firm $i$.

However, the measure in equation (3) rests upon the assumption that the systematic risk of the IPO under consideration is the same as that of the index. But it is highly unlikely that the betas of the IPOs average to unity as a number of studies (for example, Ibbotson, 1975; Affleck et al., 1996) have shown that the average betas of newly listed firms are generally higher than one. As such, the $M A A R_{i 1}$ may be upwardly biased in the sense that a higher initial performance of the IPO relative to the market could be observed. To cater for this anomaly, it would be most 
appropriate to construct a portfolio having the same risk as the IPO. Therefore, some studies ${ }^{16}$ consider initial returns which are adjusted by taking into account the returns of matching firms. However, matching-adjusted methods are rarely used, probably because it is time consuming and difficult to find matching firms unless there is a very large sample available to the researcher. Indeed, the sample size is significantly limited for the Mauritian market. As such, the $M A A R_{i 1}$ will be used as an adjustment to the raw underpricing measure. This is also consistent with the existing literature where most studies prefer to use market adjusted returns.

The average first day initial return $\left(\bar{R}_{i 1}\right)$ and the average first day market adjusted return $(\overline{M A A R})$ are calculated as:

$$
\begin{aligned}
& \bar{R}_{i 1}=1 / N \sum_{i=1}^{N} R_{i 1} \\
& \overline{M A A R}=1 / N \sum_{i=1}^{N} M A A R_{i 1}
\end{aligned}
$$

According to Suret and Kooli (2001), first day returns are generally appropriate where there is no time gap between the application closing date and the first day of trading. As such, some studies ${ }^{17}$ have used first week or first month returns to assess the degree of underpricing. The time gap for the Mauritian market is relatively long compared to developed markets. Hence it may be useful to consider first week or first month returns, although they are rarely used as measures of underpricing in the literature. To calculate the underpricing level based on first week or first month returns, the same methodologies as defined above are used.

\subsection{The buy-and-hold abnormal returns (BHAR)}

The buy-and-hold method offers an unbiased calculation of the holding period return on a portfolio of IPOs that an investor purchases and then later sells. Barber and Lyon (1997) state that

\footnotetext{
${ }^{16}$ For example, Ritter (1991), or Loughran and Ritter (1995).

${ }^{17}$ Reilly and Hatfield (1969), Beatty and Ritter (1986), and Shah (1995), amongst others.
} 
long-run event studies of stock returns attempt to determine the value of investing in the average sample firm with respect to an appropriate benchmark over the horizon of interest and as such, recommend the buy-and-hold return. According to Suret and Kooli (2001), the buy-and-hold abnormal returns have an advantage in measuring the investor experience by compounding shortterm returns. As such, the buy and hold return which is defined as a strategy where a stock is purchased at the first closing market price after going public and held for $T$ months, is defined as: ${ }^{18}$

$R_{i T}=\prod_{t=1}^{T}\left(1+r_{i t}\right)-1$

where $T$ is the number of months and $r_{i t}$ is the raw return on firm $i$ in event month $t$. The holding period return on the benchmark during the corresponding period for firm $i, R_{m T}$ is also calculated in the same manner. Based Kooli and Suret (2001), the buy-and-hold abnormal return (BHAR) is therefore defined as: ${ }^{19}$

$\operatorname{BHAR}_{i T}=\left[\prod_{t=1}^{T}\left(1+r_{i t}\right)-1\right]-\left[\prod_{t=1}^{T}\left(1+r_{m t}\right)-1\right]$

where $r_{m t}$ is the return on the benchmark during the corresponding time period.

\subsection{Hot/Cold issue Periods: Methodologies and Hypotheses}

In this section, the timings of IPOs on the SEM as well as the time-series patterns of underpricing are considered. In particular, the study will examine the number of firms listed on a yearly basis from 1989 until 2010 on the SEM to infer any discernible clustering patterns of IPO activities. Based on the studies of Loughran and Ritter (1995) and Ghosh (2004), the "hot" and "cold" markets will be defined on the basis of IPO volume. In particular, periods of hot markets will be associated with phases where there are high numbers of firms going public. As discussed in Section 3 above, the periods 1990/1991 and 1993/1994 can be considered hot issue periods. Now

\footnotetext{
${ }^{18}$ Based on Ritter (1991), the return excludes the initial underpricing period.

${ }^{19}$ However, it is observed that in contrast to Ritter (1991), the returns are market adjusted rather than control firm adjusted.
} 
that these have been defined, it is important to look at the relationship between the number of firms going public and the average initial returns. As such, the IPO volume and underpricing series, taking into account different phases in the Mauritian IPO market during 1989-2010, will be examined.

\subsubsection{The Asymmetric Information and Signalling Hypothesis}

The existence of 'hot issue periods' as discussed by Helwege and Liang (2004) and other studies, ${ }^{20}$ are described as periods with high numbers of offerings as well as high initial returns. If the issuer's aim is to maximise its issue proceeds and leave minimum money on the table, it will normally go public in periods of low initial returns. However, the empirically observed positive relationship between underpricing and IPO volume is a puzzling phenomenon. One plausible explanation for the large volume of IPOs and underpricing in the hot market is based on positive technological and productivity shocks - see Allen and Faulharber (1989) and other similar studies. ${ }^{21}$ In particular, a large number of companies will go public given a good investment climate and sound future prospects. However, low quality firms will go public along with high quality firms, and among this pool of firms, those of high quality will underprice to signal their true worth in the market and to gain the confidence of investors. As such, Allen and Faulhaber (1989) predict that a large volume of IPOs will be associated with high initial returns. Therefore, the first hypothesis is as follows:

H1: There is a positive relationship between IPO volume and average underpricing.

Moreover, the initial return series conveys any information that affects the volume of subsequent IPOs. In this respect, it will be useful to assess whether issuers in Mauritius time their IPOs in response to the information content of initial returns. Specifically, as documented by Lowry and

\footnotetext{
${ }^{20}$ Ibbotson and Jaffe (1975) and Ibbotson, and Sindelar and Ritter (1988, 1994).

${ }^{21}$ E.g., Cao and Shi (1999) and Stoughton et al. (2001).
} 
Schwert (2002), there is an apparent lead-lag relationship between IPO volume and initial returns. Therefore, the second hypothesis is as follows:

H2: There is a lead-lag relationship between the number of firms going public and the degree of underpricing.

\subsubsection{The Investment Sentiment Hypothesis and Demand for Capital Hypothesis}

According to Loughran et al. (1994), there is a "clear tendency for high [IPO] volume to be associated with market peaks..." Therefore, the relationship between the yearly SEMDEX series and the annual number of IPOs will be considered. In fact, if firms time their IPOs properly, then it can be expected that there would be many IPOs when the market is performing well since the cost of equity is lower. According to Lowry and Schwert (2002), during periods of investors' optimism, firms face favourable terms in the market, as investors are likely to overpay such that the cost of equity will be lower. In this respect, Lowry (2003) predicts that IPO volume will vary with changes in investor optimism. Thus firms will ascertain when the entire market is overvalued or when investors are willing to overpay for a specific firm relative to other firms entering the market. Also, according to Slovin et al. (1994), firms tend to make seasoned equity offerings (SEOs) when the market level has been rising. In particular, it is expected that there will be many SEOs when the market is performing well since the cost of equity is lower. It is important to consider the temporal distribution of both IPOs and SEOs as even if there is a cold market for IPOs for a given time period, there may be intense activity regarding SEOs. In brief, market peaks may be associated with a high number of SEOs rather than IPOs. Based on the above arguments, the third hypothesis is therefore:

H3: There is a positive relationship between the number of IPOs or SEOs and the stock market as a whole 


\subsubsection{The Industry Concentration Hypothesis}

Ritter (1984) shows that hot IPO markets, characterised by severe underpricing, are at times attributable to specific industries. In particular, some studies ${ }^{22}$ claim that it is more probable that a bunch of similar firms will go public as there is an information spill-over effect from observing earlier IPOs to subsequent IPOs. As such, it is important to investigate whether or not the hot market periods have a higher industry concentration. In this respect, we consider the percentage of hot and cold IPOs for each industry. Further, we also examine the distribution of hot and cold IPOs across industries and over time. This is important to assess whether hot markets across industries occur at the same time. Based on the above arguments, the fourth hypothesis is:

H4: IPOs tend to cluster in time because of the externality of information for firms in similar industries.

\subsubsection{The Changing Risk-Composition Hypothesis}

According to Ritter (1984), the observed hot issue phenomenon may be due to the changing risk composition of the IPO market. He claims that riskier issues tend to be heavily underpriced and that the hot issue period may arise when more risky firms go public. Following Ritter (1984), the steps to assess whether the changing risk composition hypothesis holds on the SEM are:

a) Classify the sample firms into several high and low risk ${ }^{23}$ categories

b) Calculate the average initial returns for each risk category

c) Assess whether the high risk firms have higher initial returns

d) If this is the case, assess whether those firms fall into the hot issue periods.

\footnotetext{
${ }^{22}$ E.g., Persons and Warther (1997), Subrahmanyam and Titman (1999), Hoffmann-Burchardi (2001), Benveniste et al. (2002) and Alti (2005).

${ }^{23}$ As in Ritter (1984), two measures (one ex ante and one ex post) are used to proxy risk. The first proxy is the annual sales before listing while the second proxy is the standard deviation of initial returns for the first 20 days after listing.
} 
In particular, one expects higher risk IPOs to exhibit higher initial returns in hot periods and lower risk IPOs to show less underpricing in cold periods. Therefore, the fifth hypothesis is:

H5: There is a positive relationship between the risk of the IPO and its average initial return.

The supplementary hypothesis for the changing risk composition hypothesis is:

H5a: High risk IPOs will exhibit high initial returns in hot periods and low risk IPOs will show low initial returns in cold periods.

\subsubsection{Market Timing and Long run Performance}

According to Helwege and Liang (2004), hot IPOs are worse performers than cold IPOs. Similarly, taking account of the limitations in the market timing abilities of managers, Trauten, Schulz and Dierkes (2007) argue that firms which go public in hot markets tend to underperform more than those going public in cold markets. In particular, if investors are irrationally optimistic, many firms will go public in times of high stock market valuation. However, based on the concept of market efficiency, this initial overreaction of investors will be reflected in long-run underperformance. As such, we will consider whether the excess returns of hot and cold IPOs differ in the long run. Therefore, the sixth hypothesis is:

H6: Firms which go public in hot markets tend to underperform more in the long run than those going public in cold markets.

\subsubsection{The Time Varying Adverse Selection Hypothesis}

Yung et al. (2008) argue that in good times, bad firms are tempted to go public and would merge with good firms. As such, there will be an increase in the quality dispersion of IPOs during booms leading to time varying adverse selection in the market for IPOs. To this effect, Yung et al. (2008) predict that IPO waves will be positively associated with a greater dispersion of quality. To test the hypothesis of time-varying adverse selection problem in the IPO market, 
Yung et al. (2008) consider the dispersion of long-run returns and as such, show that the crosssectional variance of IPO returns fluctuates over time and is much higher in hot than in cold markets. However, Lowry (2003) predicts a negative relationship between IPO volume and information asymmetry as higher information asymmetry entails higher adverse selection costs which therefore raise the costs of issue to the firm. As such, firms will find it less optimal to issue equity and will choose other modes of financing. Following this rationale, the seventh hypothesis is:

H7: The cross-sectional variance in long run abnormal returns is lower for firms going public in hot markets.

\subsection{A Multivariate Logit of the Decision to Issue in a Hot or Cold Market}

Following Helwege and Liang (2001), it is important to know how firm-specific characteristics influence the likelihood of listing between hot and cold periods. As such, a multivariate logit model, considering the probability of conducting an IPO in a hot market against a cold market is estimated. In particular, the main hypotheses, defined above in isolation, are tested using a multivariate framework. The multivariate logit model is defined as:

$$
\begin{aligned}
& \text {HOT }_{i}=\alpha+\beta_{1} \text { MAAR }_{i}+\beta_{2} \text { MARKET }_{i}+\beta_{3} \text { INDUSTRY }_{i}+\beta_{4} \text { RISK }_{i}+\beta_{6} \text { SALES }_{i}+ \\
& \beta_{7} \text { BHAR }_{i}+\beta_{8} \text { RETVAR }_{i}+u_{i}
\end{aligned}
$$

where the dependent variable is equal to 1 when a particular company goes public in a hot phase or 0 if the company goes public in a cold phase. A description of the independent variables used as well as the expected relationships is summarised in Table 1.

\subsection{Regression Model-Short Run Underpricing, Long Run Performance and Hot Issue Periods}

In this section, using a linear regression model, the impact of hot issue periods on the degree of initial underpricing is assessed. The explanatory variables, based on the existing literature, 
include proxies for the ex ante uncertainty of the firm and underwriter reputation as control variables and a dummy variable which takes into account firms which are listed in the hot or cold periods. The model employed is:

MAAR $_{i}=\alpha+\beta_{1}$ RISK $_{i}+\beta_{2}$ ZSCORE $_{i}++\beta_{3}$ BROKREP $_{i}+\beta_{4}$ AUDITREP $_{i}+\beta_{5}$ HOT $_{i}+u_{i}$

where $R_{i 1}$ and $M A A R_{i 1}$ are the first day raw and excess return (as defined above) corresponding to the issue by firm $i$ respectively. A description of the independent variables used as well as the expected relationships is summarised in Table 2.

\subsection{Regression Model- Long Run Performance and Hot Issue Period}

In this section, a multivariate regression model is employed to assess the effect of hot issue periods on long run performance of IPOs. To explain the long-run performance of IPOs, a threeyear buy and hold returns are used as dependent variable. The control variables, based on different studies, ${ }^{24}$ include proxies for ex-ante uncertainty of the firm and the windows of opportunity hypothesis. The multivariate regression employed is:

BHAR $_{i 36}=\alpha+\beta_{1}$ MAAR $_{i 1}+\beta_{2 i}$ ZSCORE $_{i}+\beta_{3}$ VOL $_{i}+\beta_{4} \operatorname{INDUSTRY~}_{i}++\beta_{5}$ HOT $_{i}+u_{i}$

where $B H A R_{i 36}$ is the market adjusted buy and hold return over the three years after the IPO, excluding initial returns. A description of the independent variables used as well as the expected relationships is summarised in Table 3.

\section{Analysis and Results}

\subsection{IPO Volume and Average Underpricing}

From Figure 1, we observed that the highest average initial returns tended to occur during the hot periods. In addition, the positively significant correlation coefficient between IPO volume and

\footnotetext{
${ }^{24}$ Ritter (1991), Beatty and Ritter (1986), Chi and Padgett (2002), Gasbarro et al. (2003).
} 
average underpricing is consistent with the empirical literature ${ }^{25}$ in that Mauritian firms take advantage of windows of opportunity to time their IPOs on the SEM. However, in the Mauritian context, the high volume of IPOs in the hot periods is also consistent with the timing of the tax reductions from $35 \%$ to $25 \%$ which were provided to listed companies by the government in the early 1990s. Tax incentives were also provided to those investing in companies listed on the SEM. As such, it is suggested that these conditions have favoured the positive relationship between IPO volume and average underpricing. Furthermore, from Figure 2, there is no clear tendency for periods of high and rising initial returns to be followed by high IPO volume. In fact, the lead-lag relationship between the number of firms going public and the average degree of underpricing is statically insignificant. ${ }^{26}$ This is inconsistent with the studies of Ibbotson and Jaffe (1975) and Ibbotson, Sindelar and Ritter $(1988,1994)$ for the US markets.

\subsection{The Number of IPOs or SEOs and Market Activity}

According to Lowry (2003), IPO volume varies with changes in investor optimism. Thus, firms will ascertain when the entire market is overvalued or when investors are willing to overpay for a specific firm relative to other firms entering the market. As such, Figure 3 evaluates the tendency for a high IPO volume to be associated with market peaks. A rising market trend is observed from 1989 until 1994, accompanied by a relatively high number of firms going public during these periods, with the exception of the year 1992. The first five years of the operating history of the SEM reflected investors' as well as firms' optimism and IPOs were timed accordingly. In effect, a total of 34 firms went public during the first five years since the inception of the SEM. This represents more than $70 \%$ of the total number of listed firms taking into account the period 1989 until 2010. However, after the hot period 1993-94, the number of firms going public has been significantly lower with a total of just 10 new listings from 1995 until 2010. However, although

\footnotetext{
${ }^{25}$ Ritter (1984), Ibbotson et al. (1988), and Helwege and Liang (2004).

${ }^{26}$ The Pearson correlation coefficient between the lagged average initial returns and the number of IPOs is equal to 0.41 with a p-value of 0.25 .
} 
the number of IPOs has been lower, the market index continued to increase, reaching its peak in 2007 and falling thereafter due to the effects of the global financial crisis. As such, the stylised fact that IPO volume varies positively with the level of market activity is called into question. In this respect, in contrast with the expectations of prior studies, ${ }^{27}$ there is no significant correlation between the SEMDEX market index and the number of IPOs. ${ }^{28}$

Given that after 1995, IPO volume fell although the market index continued to increase, it is interesting to assess whether listed firms took the opportunity to undertake seasoned offerings. As such, Figure 4 shows the number of SEOs along with the evolution of the market indices. A relatively high number of SEOs is observed for the period 1994-1995. In particular, those two years accounted for one third of the total number of SEOs from 1989 until 2009. ${ }^{29}$ Also, one must note that the 30 SEOs for the period 1989 until 2009 are distributed among just 13 firms. ${ }^{30}$ Therefore, it seems that most firms that are listed on the SEM do not intend to make a seasoned offering. This is inconsistent with the predictions of Welch (1996), who argues that firms wait to reissue as they expect a higher issue price when returning to the market. In addition, the motives of firms listed on the official market of the SEM are mostly geared towards diversification of activities rather than fund raising to support the expansion of existing lines of business. It is also observed that, as from 1996 until 2009, the number of SEOs was relatively lower, although the market indices increased at that time. In particular, the correlation between SEO volume and the SEMDEX value is statistically insignificant. ${ }^{31}$ This is inconsistent with Solvin et al. (1994) who claim that firms tend to make seasoned equity offerings (SEOs) when the market has been rising.

\footnotetext{
${ }^{27}$ Loughran et al. (1994), Lowry and Schwert (2002), and Lowry (2003), amongst others.

${ }^{28}$ The Pearson correlation coefficient between the SEMDEX value and the number of IPOs is equal to 0.63 with a pvalue of 0.28 .

${ }^{29}$ At the time of writing, no official data on the number of SEOs was available for 2010.

${ }^{30}$ Seven firms have issued SEOs more than once. These are MSM, MDIT, MCB, COURTS, SUN, MUA and GAMMA.

${ }^{31}$ The Pearson correlation coefficient between the SEMDEX and the number of SEOs is equal to -0.30 with a pvalue of 0.32 .
} 
However, as mentioned earlier, the lack of significance of the results may be due to the smaller sample size relative to other developed and developing markets. Although considerable efforts have been made to include all listed firms on the SEM within the sample, the small size of the Mauritian market still remains one the main caveats in this study.

\subsection{The Industry Clustering Hypothesis and Hot-issue Markets}

To assess whether hot or cold markets have a higher industry concentration, the percentage of the total number of IPOs for each industry for both markets is presented in Figure 5. All the offerings from the industry and sugar sectors are hot issues. This may reflect the fact that the companies in these sectors, which are traditionally old established firms, seized the opportunity to diversify their portfolios by successfully going public and using the proceeds to invest in new lines of business before the mid-1990s in a favourable pricing climate. The top three industries - the investment, commerce and industry sectors, account for $63 \%$ of the offerings in the hot markets. However, the cold markets experience greater industry clustering as the top three industries ${ }^{32}$ account for $83 \%$ of the offerings. This finding is consistent with Helwege and Liang (2004), who suggest that "... cold markets may actually exhibit more industry concentration" and that this is due to the fact "that many industries tend to have their hot markets at the same time."

However, as there are multiple hot periods, it is possible for clustering to occur in only a few of those hot periods. Figure 6 assess whether IPOs tend to cluster in time because of the externality of information for firms in similar industries. With regards to the hot period from 1989 until 1994 (excluding 1992), there is some support for industry clustering. In particular, at least $40 \%$ of the offerings are from the industry, commerce and investment sectors for the hot years 1989, 1991 and 1994 respectively. This is consistent with a number of studies ${ }^{33}$ which claim that it is

\footnotetext{
${ }^{32}$ Investment, Leisure and Hotels, and Banking and Insurance.

${ }^{33}$ Persons and Warther (1997), Subrahmanyam and Titman (1999), Hoffmann-Burchardi (2001), Benveniste et al. (2002) and Alti (2005).
} 
probable that a bunch of similar firms will go public at around the same time as there is an information spill-over effect from observing earlier to subsequent IPOs.

\subsection{Underpricing, the Changing Risk Composition Hypothesis and Hot-Cold IPOs}

Based on ex ante theories, there should be a positive relationship between the risk of IPOs and their average initial returns. Subject to this positive relationship, it is expected that high risk IPOs will exhibit high initial returns in hot periods. As such, as in Ritter (1984), two measures (one ex ante and one ex post) are used to proxy risk. The first proxy is the annual sales before listing (Table 4) while the second proxy is the standard deviation of initial returns for the first 20 days (Table 5). When segmenting through the sales category, the differences between the average initial returns of hot $(11.55 \%)$ and cold $(3.17 \%)$ issues are statistically insignificant. This insignificant result may be due to the sample size problem relating to the small number of offerings in cold periods when segmentation by sales category is applied. However, when considering all firms for the periods 1989-2005, the hot issues exhibit on average higher levels of underpricing than the cold issues. In particular, IPOs in hot periods earn on average $7.52 \%$ more than IPOs in cold periods and this difference is statistically significant at the $10 \%$ level. The existence of 'hot issue periods' on the Mauritian market shows similar characteristics to those discussed by Helwege and Liang (2004) and other studies ${ }^{34}$ where there are a high number of offerings as well as high initial returns.

From Table 4, the level of the firm's annual sales prior to going public is used as a measure of risk such that the sample is partitioned into two groups: low and high sales categories. For the 1989-2005 period, Table 4 shows that the higher risk (lower sales) firms have higher average initial returns than lower risk firms. This is consistent with the ex-ante theories ${ }^{35}$ in that there is a

\footnotetext{
${ }^{34}$ Ibbotson and Jaffe (1975) and Ibbotson, Sindelar and Ritter (1988, 1994).

${ }^{35}$ Ritter (1984), Beatty and Ritter (1986), Cao and Shi (1999) and Stoughton et al. (2001), and Ghosh (2004), amongst others.
} 
positive relationship between the risk of the IPO and the degree of underpricing. Also, the higher risk (lower sales) firms exhibit an average initial return of $17.04 \%$ (significant at the 5\% level) in hot periods while the low risk IPOs (higher sales) firms show an average initial return of only $7.98 \%$ (significant at the $10 \%$ level) in cold periods, consistent with the changing risk composition hypothesis since there are more firms which are risky coming to the market in the hot periods.

Similarly, from Table 5, when ex post standard deviation is used as a risk proxy, the same monotonic relationship between risk and average initial returns is found. Also, high risk IPOs, on average, experience the highest degree of underpricing $(22.76 \%$, statistically significant at the $5 \%$ level) in hot periods. Moreover, there are more risky IPOs during the hot periods. Due the small sample size problem, the mean differences are statistically insignificant between the hot and cold issues when the sample is partitioned based on the risk level of the firm. However, overall, the results support the predictions of the changing risk composition hypothesis.

\subsection{Market Timing and the Long Run Performance of Hot and Cold IPOs}

According to Trautena, Schulz and Dierkesc (2007), firms which go public in hot markets tend to underperform more than those going public in cold markets. One explanation for the bad performance of hot IPOs is related to market timing where managers take their firms public when market optimism prevails such that the IPOs are overvalued. However, when later the market learns their true value, underperformance results. In this respect, Table 6 reports the mean stock returns of post-listing three year buy-and-hold strategies for 44 Mauritian IPO companies from 1989-2005, categorised by hot/cold issues. According to Helwege and Liang (2004), "if "hot" is defined by the volume of IPOs in the month of the offering, hot market firms are typically worse performers than cold firms". However, on the Mauritian market, it seems that firms going public in hot IPO markets perform on average better than those going public in cold markets, even when 
the hot issue sub-periods are considered. However, the difference in underperformance between hot and cold issues is statistically insignificant. This result is inconsistent with a number of studies $^{36}$ and as such, when comparing the long-run performance of hot and cold issues overall, the results suggest that firms which go public in the hot markets or in years when there are large numbers of IPOs, do not necessarily underperform more in the long run than those going public in cold markets or in years when there are smaller numbers of IPOs.

\subsection{The Time Varying Adverse Selection Hypothesis: Return Variance across Hot and Cold markets}

Yung et al. (2008) argue that there will be an increase in the quality dispersion of IPOs during booms leading to time-varying adverse selection in the market for IPOs. In particular, they consider the variances of long run returns as a proxy for the variation in IPO firm quality. However, Lowry (2003) predicts a negative relationship between information asymmetry and volume. Table 7 shows that the cross-sectional variance in long run abnormal returns is lower for firms going public in hot markets, although the differences are statistically significant. This suggests that the hot markets tend to experience a lower dispersion in firm quality than cold markets.

\subsection{The Firm-Specific Characteristics of IPOs during Hot and Cold Markets}

Based on the above hypotheses, firm-specific characteristics will normally impact on the likelihood of listing in the hot and cold markets. Following Helwege and Liang (2001), the likelihood of an IPO in a hot phase in comparison with a cold phase, we consider conditioning upon the companies that actually went public during these phases. From Table 8, the results do not support the industry clustering, the market timing or the demand for capital hypotheses as hot market IPOs are not likely to be listed when the market is performing well. However, consistent

${ }^{36}$ Cook et al. (2003), Helwege and Liang (2004), Ljungqvist et al. (2006), Trauten et al. (2007). 
with previous results, hot market IPOs have higher initial returns, in line with the signalling hypothesis. Also, consistent with the risk changing composition hypothesis, the hot issue period may reflect the time where more risky firms are likely to go public. Furthermore, the results support the time adverse selection hypothesis as hot market firms are more likely to have lower cross sectional return variance than cold market firms. This shows that there is more dispersion of firms' quality in cold than hot markets on the SEM.

\subsection{Short Run Underpricing and the Hot Issue Period}

In this section, the impact of hot issue periods on the degree of underpricing is assessed. The dependent variables are the initial raw and market adjusted returns of companies and the independent variables are defined as follows: RISK is the after market risk level of the IPO, ZSCORE is Altman's Z-score prior to listing, BROKREP is a measure of the stockbroker's reputation, AUDITREP is the auditor's reputation. In addition, the regression model incorporates a dummy variable (HOT), which takes the value one for firms which are listed during the hot periods 1989 until 1991 and 1993-1994, and zero otherwise. The results are reported in Table 9. The bivariate analysis from models 1 and 3 shows that firms in hot periods generate higher initial raw and market adjusted returns than firms in cold periods. However, when controlling for other factors, the hot issue phenomenon is statistically insignificant in explaining the short-run underpricing. This suggests that factors such as the auditor's reputation, financial strength and the risk of the IPO are more important than the hot issue phenomenon with regards to the decision of firms to underprice (or not) their issues on the SEM.

\subsection{Long Run Performance and the Hot Issue Period- Regression Analysis}

According to Helwege and Liang (2004), hot IPOs are worse long-term performers than cold IPOs. As such, we consider whether or not the hot issue phenomenon can explain the long run performance of IPOs on the SEM. The results are reported in Table 10. The bivariate analysis 
from model 1 shows that firms in hot markets are not worse performers. The findings also indicate that the hot issue phenomenon is also insignificant when controlling for other factors. The results further suggest that financial strength is more important than the hot issue phenomenon in explaining the long run performance of IPOs. As such, consistent with our earlier predictions, there seems to be no support for the market timing and long-run performance hypothesis.

\section{Conclusions}

This paper has examined the characteristics of the hot issue market from the inception of the Stock Exchange of Mauritius until 2010. The study reveals that the highest number of admissions for listing was concentrated around the periods 1989 until 1991 and 1993 to 1994, and as such, following Ritter (1984) and Ibbotson and Jaffe (1975), we term these the "hot" issue periods. When looking at the timing of IPOs, high initial returns are not followed by a high issue volume. When considering the hot /cold issues by sector, the results show that all the offerings from the industry and the sugar sectors are hot issues and thus there is some support for sectoral clustering (and the cold markets also clustered by industry), consistent with the asymmetric information and industry concentration hypotheses. For the period 1989-2005, the hot issues on average exhibit higher levels of underpricing than the cold issues and there is support for the asymmetric and signalling hypothesis based on the multivariate logit model. In addition, the results support the predictions of the changing risk composition hypothesis where high risk IPOs on average experience the highest degree of underpricing in hot periods. Furthermore, there is support for the time-varying risk hypothesis in that the cross-sectional variance seems to be statistically different in the cold and hot market phases. Finally, the regression analysis reveals that the hot-issue phenomenon is not a key driver in explaining the short-run underpricing or the long run performance of IPOs on the SEM. 
As well as determining whether hot or cold market issuance affects price performance that will drive the cost of equity in a fashion that will concern financial managers as described above, our research also has implications for investors and hedge fund managers who seek to profit from transacting in the stocks of new issues. Given that hot issues are likely to be more underpriced than cold issues, this would imply that investors should attempt to buy and hold hot issues in preference to cold issues over a very short time period. In the longer run, however, while on average all IPOs show underperformance, those companies coming to market during hot periods show more negative abnormal returns than those issued during cold periods

While our study is a first and hopefully definitive study of the Mauritian hot issue phenomenon, our findings suggest a number of avenues for further research. It would be of considerable interest to focus on an analysis of earnings management to assess the level of manipulation in earnings in hot and cold markets and whether firms are more likely to overstate earnings in hot markets in order to bring forward their listings while conditions are favourable for achieving high valuations.

Another line of research would be to undertake a study involving a pan-African study with a larger sample of IPOs to assess whether the results reported in this study are common to all emerging hot issue markets where investors are less sophisticated and liquidity low, or whether they are unique characteristics pertaining only to Mauritian IPOs. One could also extend the present study to analyse the effect of ownership retention, which is considerable, in the Mauritian IPO market. Grinblatt and Hwang (1989) argue that retained shares can be used as signals to express the concealed information about the firm value to uninformed investors. Thus, the predictions of Leland and Pyle (1977) and Grinblatt and Hwang (1989) maintain that retained ownership act as a signal for higher quality of the firm and as such, should be related with greater IPO underpricing. On the other hand, Chen and Strange (2004) find that underpricing is 
negatively related to equity retention for the Chinese market and so this is clearly an area where significant questions remain unanswered.

\section{References}

Affleck-Graves, J., Hedge, S. and Miller, R.E., 1996. Conditional price trends in the aftermarket for initial public offerings, Financial Management, 25, 25-40.

Aggarwal, R., Leal, R., and Hernandez, L., 1993. The aftermarket performance of initial public offerings in Latin America, Financial Management, 22, 42-53.

Allen, F., and Faulhaber G.R., 1989, Signaling by Underpricing in the IPO Market, Journal of Financial Economics, 23, 303-323.

Alti, A., 2005. IPO Market Timing, Review of Financial Studies, 18, 1105-1138.

Altman, E., I., 1968. Financial Ratios, Discriminant Analysis and the Prediction of Corporate Bankruptcy, Journal of Finance, 189-209.

Altman, E., I., 2000. Predicting Financial Distress Of Companies: Revisiting The Z-Score and Zeta Models: Altman's Stern School of Business, New York University web page :Available from URL: http://pages.stern.nyu.edu/ ealtman/Zscores.pdf

Alvarez, S. and Gonzalez V.,M., 2001. Long-Run Performance of Initial Public Offerings (IPOs) in the Spanish Capital Market. Annual European Financial Management Association Meetings

Baker, M. and Wurgler J., 2000. The equity share in new issues and aggregate stock returns, Journal of Finance, 55, 2219-2257.

Barber B.M. AND Lyon J.D., 1997, Detecting Long-Run Abnormal Stock Returns: The Empirical Power and Specification of Test Statistics, Journal of Financial Economics, 43, 341-372.

Beatty, R. and Ritter, J.R., 1986. Investment Banking, Reputation, and the Underpricing of Initial Public Offerings, Journal of Financial Economics, 15, 213-232.

Benveniste, L.M., Busaba, W.Y., and Wilhelm, W.J., Jr., 2002. Information Externalities and the Role of Underwriters in Primary Equity Markets, Journal of Financial Intermediation, 11, 61-86

Brau, J. and Fawcett S., 2006. Initial public offerings: an analysis of theory and practice, The Journal of Finance, 90 (1), 399-436.

Cao, M. and Shi S., 1999. Publicity and clustering of IPO underpricing, Working Paper, Queen's University.

Chemmanur, T., and Fulghieri P., 1999. A Theory of the Going-Public Decision, Review of Financial Studies, 12, 249-279.

Chen, J. AND Strange, R., 2004. The Evolution of Corporate Governance in China. The Management Centre Research Papers No. 25, King's College, London, UK.

Dawson, S, M., 1987. Secondary stock market performance of initial public offers: Hong Kong, Singapore and Malaysia, Journal of Business Finance \& Accounting, Spring, 65-76. 
Dorn, D., 2002. Does Sentiment Drive the Retail Demand for IPOs? Working paper, Columbia University.

Fink, J., Fink K., Grullon G. and Weston J., 2005. IPO Vintage and the Rise of Idiosyncratic Risk, Working paper, Rice University.

Gasbarro, D., Bundoo, S. and Zumwalt J.K., 2003. Underpricing and Aftermarket Performance of IPO Firms in Mauritius. Journal of Emerging Market Finance, 2 (3), 315-335.

Ghosh, S., 2004, Underpricing of IPOs: The Indian Experience over the Last Decade, Working Paper, Reserve Bank of India.

Grinblatt, M. AND Hwang, C.Y., 1989. Signalling and the Pricing of New Issues. Journal of Finance, 44, 393-420.

Günther, S. and Rummer, M., 2006. The hot-issue period in Germany: what factors drove IPO underpricing? in Initial Public Offerings: an international perspective, $I^{\text {st }}$ edition by Greg N. Gregoriou. Burlington: Elsevier.

Hameed, A. And Lim, G. H., 1998.Underpricing and firm quality in initial public offerings: evidence from Singapore, Journal of Business Finance \& Accounting, Vol. 25, 455-468.

Helwege, J and Liang N., 2001. Initial Public Offerings in Hot and Cold Markets, Working Paper, Ohio State University and Board of Governors of the Federal Reserve System.

Helwege, J and Liang N., 2004. IPOs in hot and cold markets, Journal of Financial and Quantitative Analysis, 39, 541-69.

Hoffmann-Burchardi, U., 2001. Clustering of Initial Public Offerings, Information Revelation and Underpricing. European Economic Review, 45, 353-383.

Howe, J. and Zhang S., 2005. Underwriting in Hot and Cold Markets, Working paper, University of Missouri - Columbia.

Ibbotson, R.G., 1975. Price Performance of Common Stock New Issues, Journal of Financial Economics, 2, 235-272.

Ibbotson, R.G. and Jaffe J.F., 1975. "Hot Issue” Markets, Journal of Finance, 30, 1027-1042.

Ibbotson, R.G., Sindelar J. and Ritter J., 1988. Initial public offerings, Journal of Applied Corporate Finance, 1, 37-45.

Ibbotson, R.G., Sindelar J. and Ritter J., 1994. The market's problems with the pricing of initial public offerings, Journal of Applied Corporate Finance, 7, 66-74.

Jain, B. and Kini, O., 1994. The post-issue operating performance of IPO firms, Journal of Finance, 49, 1699-1726.

Jain, B. and Kini, O., 2006, Industry clustering of initial public offerings, Managerial and Decision Economics, 27, 1-20.

Jenkinson, T.J., and Ljungqvist, A., 2001, Going Public: The Theory and Evidence on How Companies Raise Equity Finance, 2nd ed. (Oxford University Press, Oxford, England).

Lee, C., Shleifer, A. and Thaler T., 1991. Investor Sentiment and the Closed-end Fund Puzzle, Journal of Finance, 46, 75-109. 
Leland, H. AND Pyle, H., 1977. Informational Asymmetries, Financial Structure, and Financial Intermediation. Journal of Finance, 32 (2), 371-387.

Ljungqvist, A., 1997. Pricing Initial Public Offerings: Further Evidence from Germany, European Economic Review, 41, 1309-1320.

Ljungqvist, A., Nanda, V. and Singh, R., 2005. Hot Markets, Investor Sentiment and IPO Pricing, Journal of Business, 79, 1667-1702.

Ljungqvist, A., and Wilhelm W.J., 2003. IPO Pricing in the Dot-Com Bubble, Journal of Finance, 58, 723-752.

Löffler, G., 2000. Zeichnungsrenditen am Neuen Markt: Gleichgewicht oder Ineffizienz? Working Paper, Frankfurt University

Loughran, T. and Ritter J.R., 1995. The New Issue Puzzle, Journal of Finance 50, $23-51$.

Loughran, T. and Ritter J.R., 2004. Why Has IPO Underpricing Increased Over Time? Financial Management, 33, 5-37.

Loughran, T., Ritter J.R., and Rydqvist K., 1994. Initial public offerings: International insights, PacificBasin Finance Journal, 2, 165-199.

Lowry, M., 2003. Why does IPO volume fluctuate so much? Journal of Financial Economics, 67, 3-40.

Lowry, M. and Schwert, G.W., 2002. IPO market cycles: Bubbles or sequential learning? Journal of Finance, 57, 1171-1200.

Lucas, D. and McDonald, R. L., 1990. Equity Issues and Stock Price Dynamics, Journal of Finance, 45, 1019-1043

Lyn, E., O. And Zychowicz, E. J.2002. The performance of new equity offerings in Hungary and Poland, Global Finance Journal, 14, 181-195.

Omran, M.,2005. Initial and Aftermarket Performance of Share Issue Privatization in the Egyptian Stock Market. The Journal of Financial Research, 2, 215-234.

Pagano, M., Panetta, F., and Zingales, L., 1998. Why Do Companies Go Public? An Empirical Analysis, Journal of Finance, 53, 27-64.

Persons, J. and Warther, V., 1997, Boom and bust patterns in the adoption of financial innovations, Review of Financial Studies 10, 939-968.

Procianoy, J.L. And Cigerza, G.C., 2007. IPOs in emerging markets: A comparison of Brazil, India and China, Working paper, Universidade Federal do Rio Grande do Sul.

Rajan, R. and Servaes, H., 1997. Analyst Following of Initial Public Offerings, Journal of Finance 52, 507-529.

Reilly, F.K. and Hatfield, K., 1969. Investor Experience with New Stock Issues, Financial Analyst Journal, 25, 73-80.

Ritter, J.R., 1984. The Hot Issue Market of 1980, Journal of Business, 57, 215-240.

Ritter, J.R., 1991, The Long-Run Performance of Initial Public Offerings, Journal of Finance, 46, 3-27. 
Shah, A., 1995. The Indian IPO Market: Empirical Facts. Technical Report, Centre for Monitoring Indian Economy Mumbai.

Slovin, M.B., Sushka, M.E., Bendeck, Y.M., 1994. Seasoned common stock issuance following an IPO, Journal of Banking and Finance, 18(1), 207-226.

Stoughton, N.M., Wong, K.P. and Zechner J., 2001. IPOs and Product Quality, Journal of Business, 74.

Subrahmanyam, A. and Titman, S., 1999. The going public decision and the development of financial markets, Journal of Finance, 54, 1045-82.

Suret, J. and Kooli, M., 2001. The Aftermarket Performance of Initial Public Offerings in Canada, Scientific Series, 1-34.

Teoh, S. H., Welch, I. and Wong T.J., 1998. Earnings Management and the Long-Run Market Performance of Initial Public Offerings, Journal of Finance, 53(6), 1935-74

Trauten, A, Schulz R.C., and Dierkes, M., 2007. The performance of IPO investment strategies and pseudo market timing - Evidence from Germany, Working Paper, Westfälische Wilhelms-Universität Münster.

White, H., 1980. A heteroscedasticity-consistent covariance matrix estimator and a direct test for heteroscedasticity, Econometrica 48 (4): 817-838

Yung, C., Colak, G. and Wang, W., 2008. Cycles in the IPO Market, Journal of Financial Economics, 89 (1), pp. 192-208

Zingales, L., 1995, Insider Ownership and the Decision to Go Public, Review of Economic Studies, 62, 425-448. 
Figure 1: Market indices and Number of Listed Firms

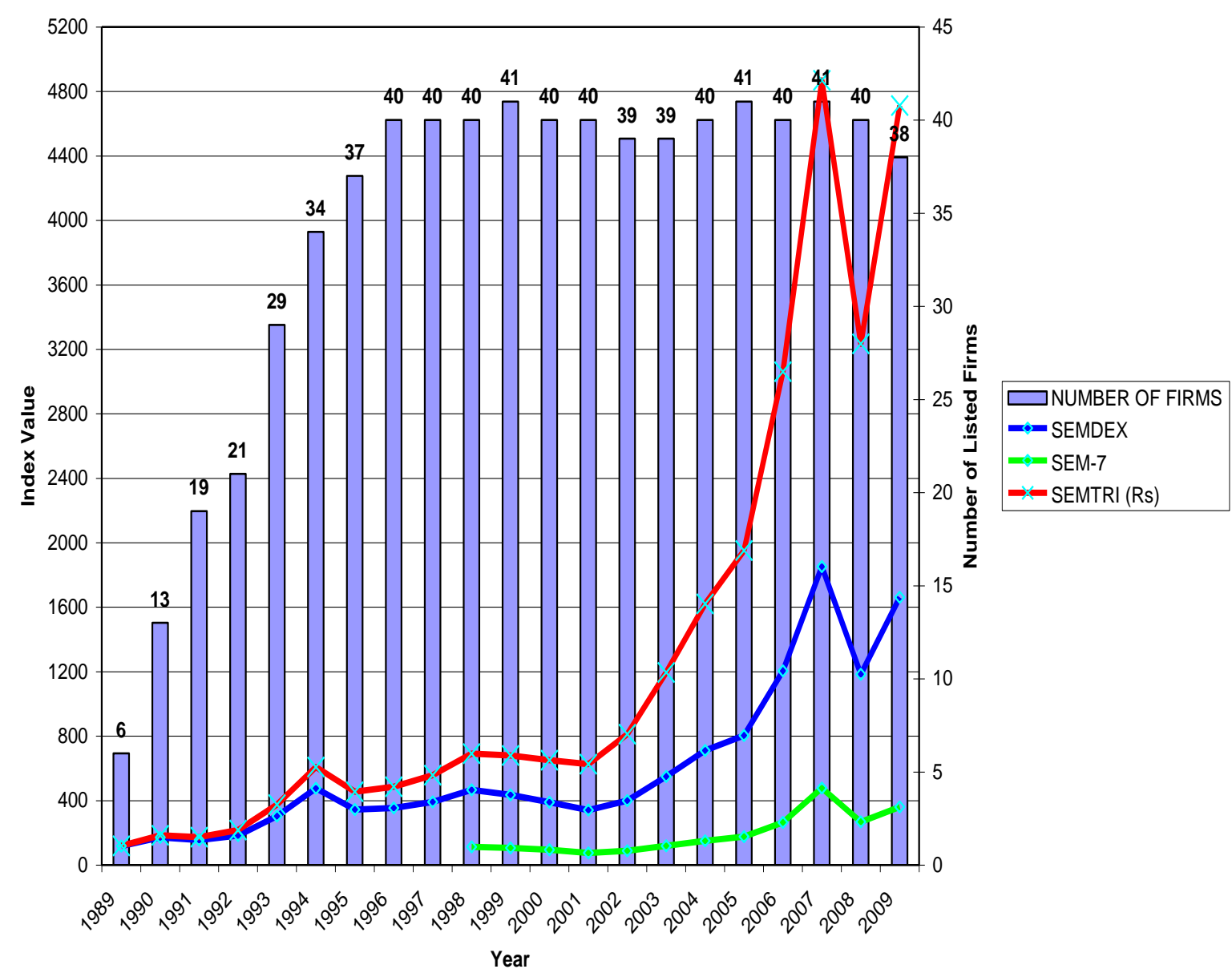

Source: SEM FACTBOOK 2010 and Author's Computation 
Figure 2: The number of IPOs and average underpricing

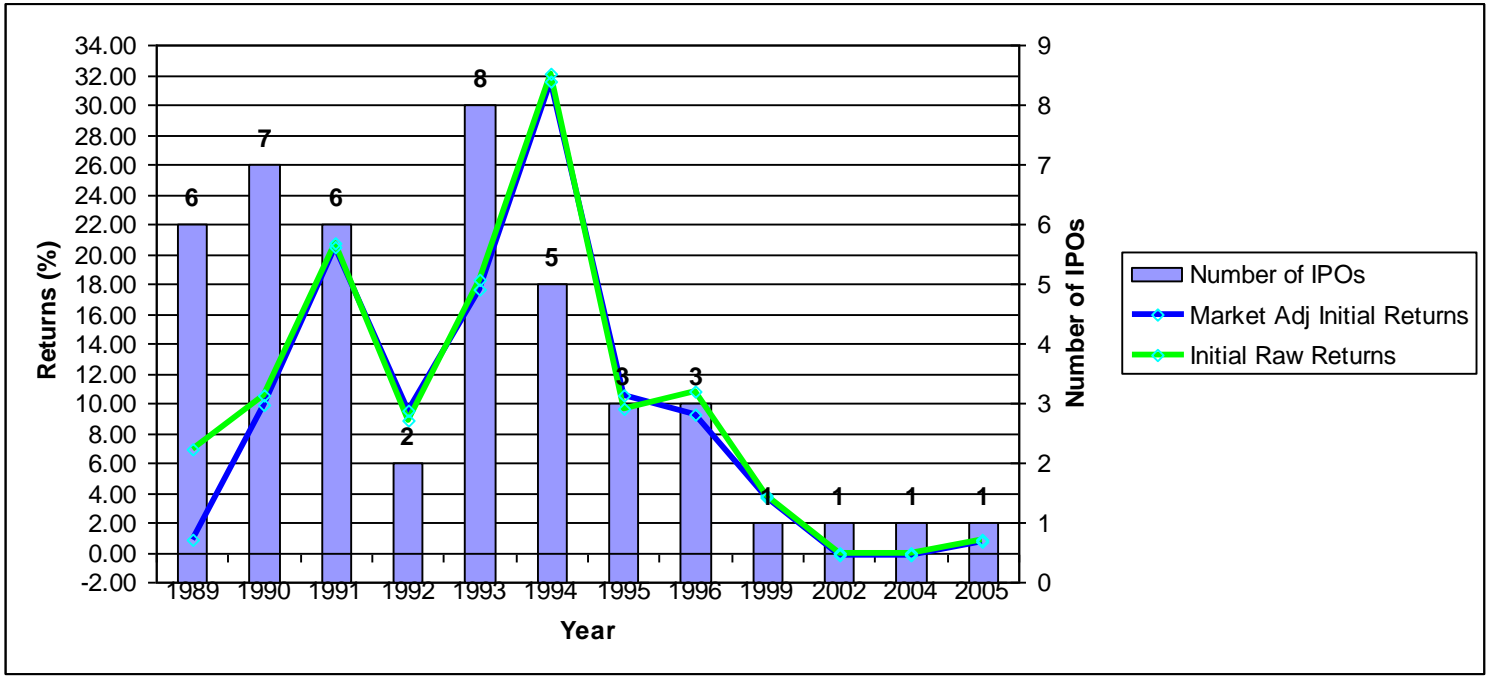

Figure 3: The number of IPOs and Market Activity

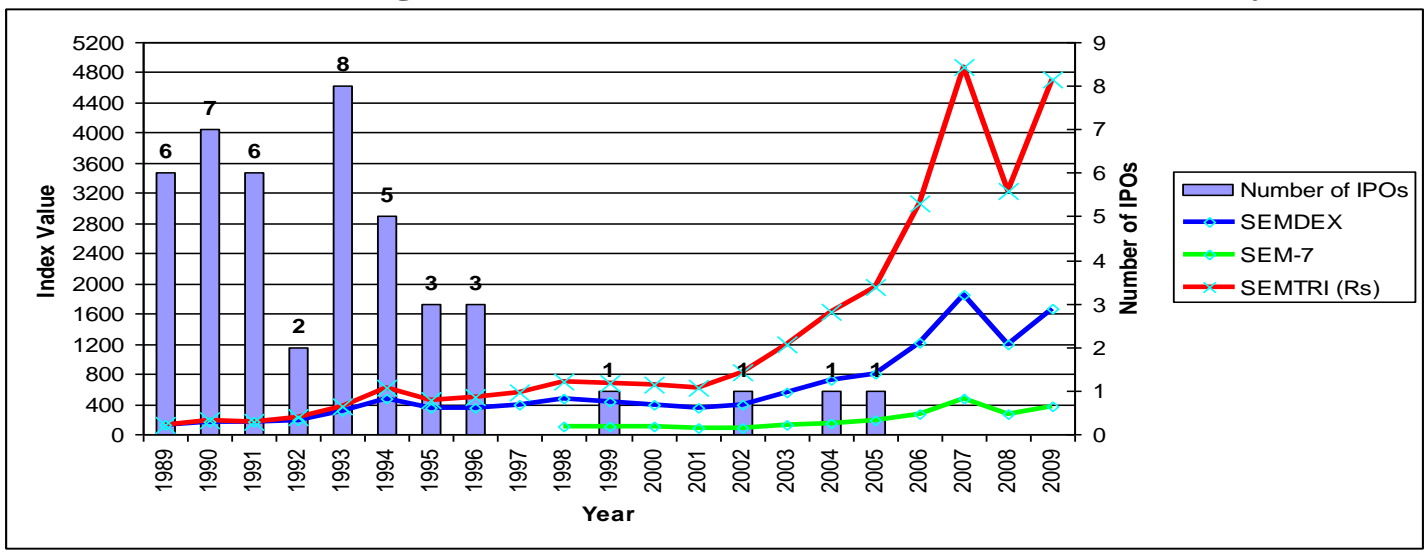

Figure 4: The number of SEOs and Market Activity

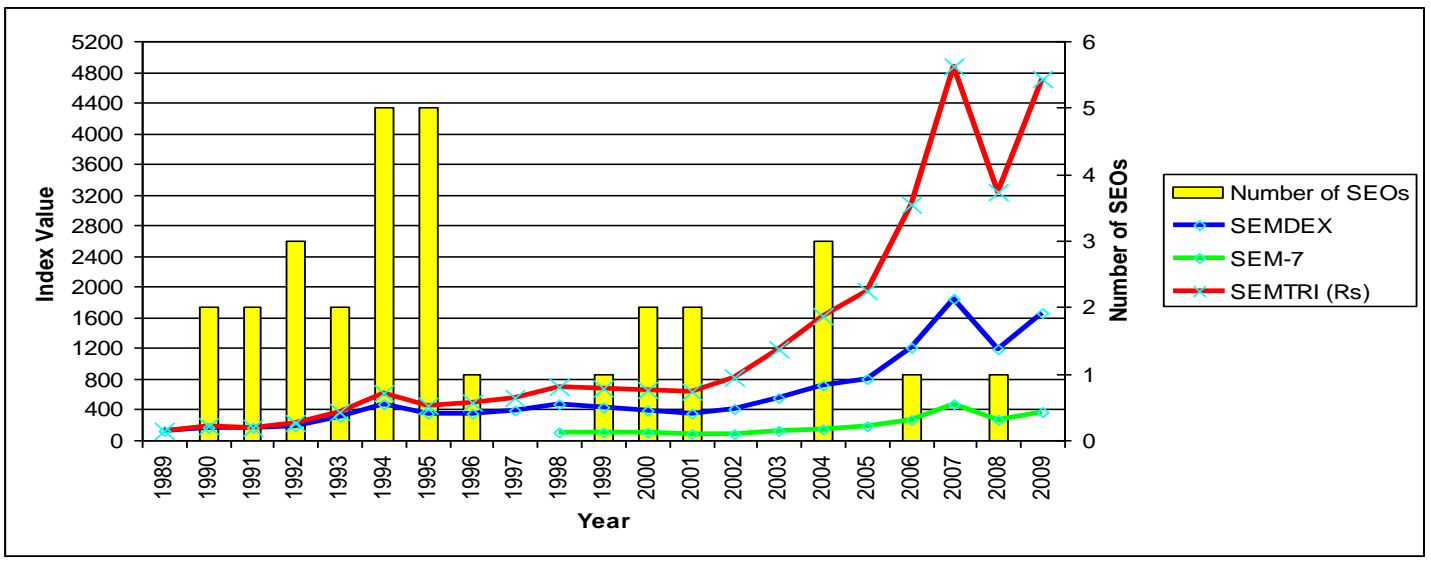


Figure 5: IPOs by Sector, Hot and Cold Markets

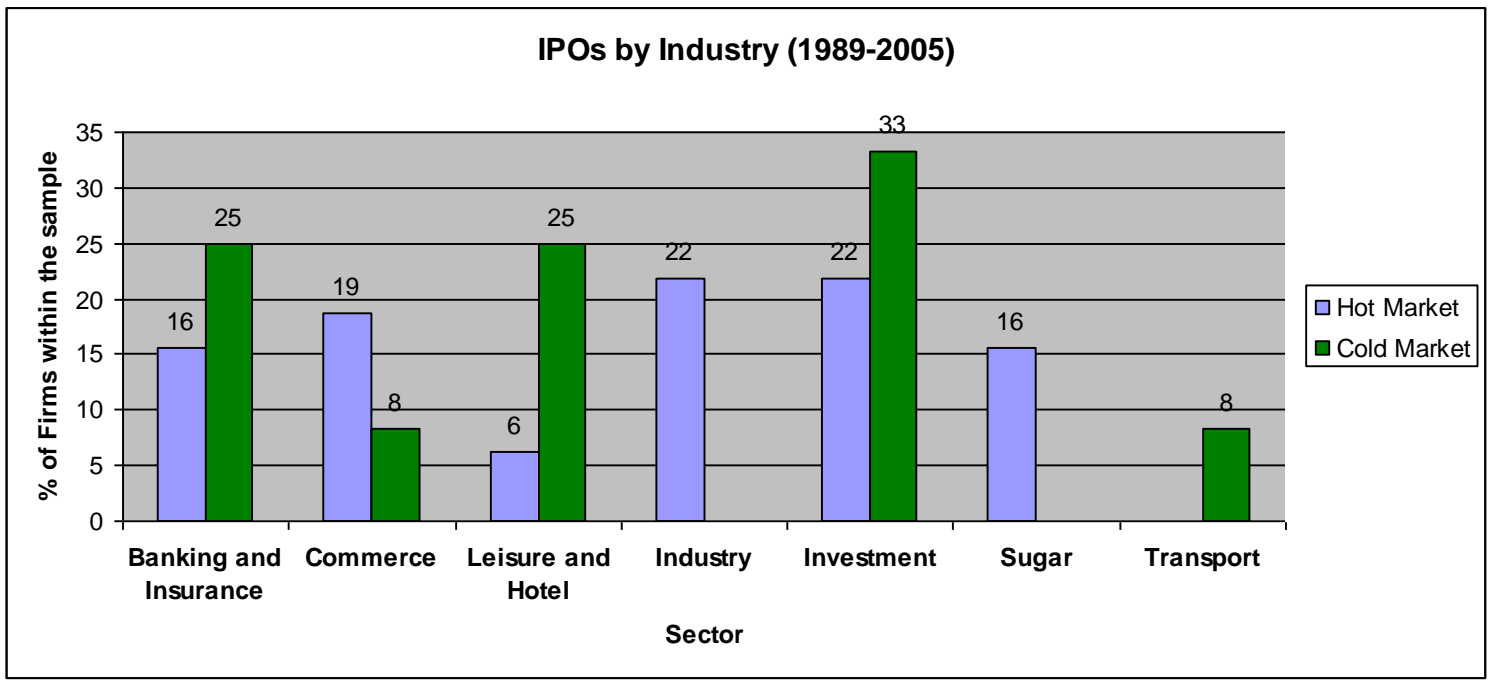

Figure 6: Hot and Cold Markets by Sector over Time

Hot and Cold Markets by Industry across time


TABLE 1: DESCRIPTION AND COMPUTATION OF EXPLANATORY VARIABLES USED IN THE STUDY OF THE DECISION TO ISSUE IN A HOT OR COLD MARKET

\begin{tabular}{|c|c|c|c|}
\hline $\begin{array}{l}\text { EXPLANATORY } \\
\text { VARIABLES }\end{array}$ & $\begin{array}{l}\text { EXPECTED } \\
\text { SIGN }\end{array}$ & DESCRIPTION & CALCULATION \\
\hline \multicolumn{4}{|c|}{ Asymmetric Information and Signalling Hypothesis } \\
\hline $\begin{array}{l}\text { MAAR = Short- } \\
\text { Run Underpricing }\end{array}$ & + & $\begin{array}{l}\text { Allen and Faulhaber (1989) predict } \\
\text { that a large volume of IPOs is } \\
\text { associated with high initial returns. In } \\
\text { particular, signalling theory claims } \\
\text { that good firms would be listed } \\
\text { during the hot market and underprice } \\
\text { more to signal their true quality. }\end{array}$ & $\begin{array}{l}\text { The one day excess return corresponding } \\
\text { to the issue of the firm } i \text {. }\end{array}$ \\
\hline \multicolumn{4}{|c|}{ Investment Sentiment Hypothesis and Demand for Capital Hypothesis } \\
\hline $\begin{array}{l}\text { MARKET= } \\
\text { Market } \\
\text { performance prior } \\
\text { to the issue }\end{array}$ & + & $\begin{array}{l}\text { If firms time their IPOs properly, } \\
\text { then it can be expected that there } \\
\text { would be many IPOs when the } \\
\text { market is performing well since the } \\
\text { cost of equity is lower. }\end{array}$ & $\begin{array}{l}\text { The percentage change in the SEMDEX } \\
\text { index for the three month period prior to } \\
\text { the issue period of the firm. }\end{array}$ \\
\hline \multicolumn{4}{|c|}{ Industry Concentration Hypothesis } \\
\hline $\begin{array}{l}\text { INDUSTRY = } \\
\text { Industry Clustering } \\
\text { Dummy }\end{array}$ & + & $\begin{array}{l}\text { The likelihood of IPOs getting listed } \\
\text { from a particular industry is more } \\
\text { during the hot period. }\end{array}$ & $\begin{array}{l}\text { Dummy variable takes a value one if } \\
\text { firms are in the non-financial sector and } \\
\text { zero otherwise. }\end{array}$ \\
\hline \multicolumn{4}{|c|}{ The Changing Risk-Composition Hypothesis } \\
\hline $\begin{array}{l}\text { RISK }=\text { Aftermarket } \\
\text { risk level of the IPO }\end{array}$ & + & $\begin{array}{l}\text { The hot issue period may reflect the } \\
\text { period where more risky firms go } \\
\text { public. }\end{array}$ & $\begin{array}{l}\text { Risk is defined as the aftermarket } \\
\text { standard deviations based on the first } 20 \\
\text { daily returns in the aftermarket, excluding } \\
\text { the initial returns. }\end{array}$ \\
\hline $\begin{array}{l}\text { SALES=Annual } \\
\text { Turnover of the } \\
\text { firm }\end{array}$ & - & $\begin{array}{l}\text { The higher risk (lower sales) firms } \\
\text { are more likely to go public in hot } \\
\text { rather than cold markets. }\end{array}$ & $\begin{array}{l}\text { The log of the firm's annual sales prior to } \\
\text { going public }\end{array}$ \\
\hline \multicolumn{4}{|c|}{ Market Timing and Long run Performance } \\
\hline $\begin{array}{l}\text { BHAR= Long } \\
\text { Performance } \\
\text { IPOs }\end{array}$ & - & $\begin{array}{l}\text { Trauten, Schulz and Dierkes (2007) } \\
\text { argue that firms which go public in } \\
\text { hot markets tend to underperform } \\
\text { more than those going public in cold } \\
\text { markets. }\end{array}$ & $\begin{array}{l}\text { The buy and hold return which is defined } \\
\text { as a strategy where a stock is purchased at } \\
\text { the first closing market price after going } \\
\text { public and held until the earlier of its } \\
\text { three year anniversary }\end{array}$ \\
\hline \multicolumn{4}{|c|}{ Time Varying Adverse Selection Hypothesis } \\
\hline $\begin{array}{l}\text { RETVAR }=\text { Cross } \\
\text { section variance of } \\
\text { IPO returns }\end{array}$ & + or - & $\begin{array}{l}\text { The cross section variance of IPO } \\
\text { returns fluctuate over time and would } \\
\text { depend on specific periods. }\end{array}$ & $\begin{array}{l}\text { The 12-month returns variance of the IPO, } \\
\text { excluding initial returns. }\end{array}$ \\
\hline
\end{tabular}


TABLE 2: DESCRIPTION AND COMPUTATION OF EXPLANATORY VARIABLES USED IN THE STUDY OF SHORT-RUN UNDERPRICING

\begin{tabular}{|c|c|c|c|}
\hline $\begin{array}{l}\text { EXPLANATORY } \\
\text { VARIABLES }\end{array}$ & $\begin{array}{c}\text { EXPECTED } \\
\text { SIGN }\end{array}$ & DESCRIPTION & CALCULATION \\
\hline $\begin{array}{l}\text { RISK }=\text { Aftermarket } \\
\text { risk level of the IPO }\end{array}$ & + & $\begin{array}{l}\text { The more the price of the new } \\
\text { company is uncertain, the more } \\
\text { discount an issuer will offer in selling } \\
\text { the IPO. }\end{array}$ & $\begin{array}{l}\text { Risk is defined as the Standard } \\
\text { Deviation (SD) of the returns after the } \\
\text { listing of the IPO over next thirty days. }\end{array}$ \\
\hline $\begin{array}{l}\text { ZSCORE = Ex-ante } \\
\text { Financial Strength }\end{array}$ & - & $\begin{array}{l}\text { IPOs with high financial strength } \\
\text { should be associated with lower } \\
\text { underpricing due to their lower ex-ante } \\
\text { uncertainty. }\end{array}$ & $\begin{array}{l}\text { An Altman Z-score is calculated based } \\
\text { on figures prior to the year of listing to } \\
\text { proxy the ex-ante financial strength. }\end{array}$ \\
\hline $\begin{array}{l}\text { BROKREP = Stock } \\
\text { broker's reputation }\end{array}$ & - & $\begin{array}{l}\text { Prestigious underwriters are associated } \\
\text { with a lower degree of underpricing } \\
\text { since they eliminate some uncertainties } \\
\text { and signal favourable private } \\
\text { information. }\end{array}$ & $\begin{array}{l}\text { Sponsoring stockbroker reputation is } \\
\text { proxied by the number of issues the } \\
\text { stockbroker has sponsored. A dummy } \\
\text { variable is then used where a value of } \\
\text { one indicates that the firm has been } \\
\text { sponsored by a highly prestigious stock } \\
\text { broker. }\end{array}$ \\
\hline $\begin{array}{l}\text { AUDITREP } \\
\text { Auditor's } \\
\text { Reputation }\end{array}$ & - & $\begin{array}{l}\text { The uncertainty surrounding the firm } \\
\text { will fall as reputation increases. In } \\
\text { particular, high quality audit firms will } \\
\text { be associated with lower underpricing. }\end{array}$ & $\begin{array}{l}\text { Auditor's reputation is calculated by } \\
\text { taking the ratio of the number of IPOs } \\
\text { audited to the total number of IPOs } \\
\text { during the sample period. A dummy } \\
\text { variable is then used where a value of } \\
\text { one indicates that the firm has been } \\
\text { audited by a highly quality auditor. }\end{array}$ \\
\hline $\begin{array}{l}\text { HOT }=\text { Dummy } \\
\text { Variable for the hot } \\
\text { issue periods }\end{array}$ & + & $\begin{array}{l}\text { Allen and Faulhaber (1989) predict that } \\
\text { a large volume of IPOs is associated } \\
\text { with high initial returns. In particular, } \\
\text { signalling theory claims that good } \\
\text { firms would be listed during the hot } \\
\text { market and underprice more to signal } \\
\text { their true quality. }\end{array}$ & $\begin{array}{l}\text { A dummy variable takes the value one } \\
\text { for firms which are listed during the hot } \\
\text { periods } 1989 \text { until } 1991 \text { and } 1993 / 1994 \text {, } \\
\text { and zero otherwise. }\end{array}$ \\
\hline
\end{tabular}


TABLE 3: DESCRIPTION AND COMPUTATION OF EXPLANATORY VARIABLES USED IN THE STUDY OF LONG-RUN PERFORMANCE

\begin{tabular}{|c|c|c|c|}
\hline $\begin{array}{l}\text { EXPLANATORY } \\
\text { VARIABLES }\end{array}$ & $\begin{array}{c}\text { EXPECTED } \\
\text { SIGN }\end{array}$ & DESCRIPTION & CALCULATION \\
\hline $\begin{array}{l}\text { MAAR = Short- } \\
\text { Run Underpricing }\end{array}$ & - & $\begin{array}{l}\text { It is noted that Aggarwal and Rivoli } \\
\text { (1990), Ritter (1991) and Levis (1993) } \\
\text { reported a negative relationship between } \\
\text { underpricing and aftermarket } \\
\text { performance of IPOs which is consistent } \\
\text { with the overreaction hypothesis. }\end{array}$ & $\begin{array}{l}\text { One day excess return corresponding } \\
\text { to the issue by firm } i, R_{i 1} \text { is the one } \\
\text { day return for firm } i \text {, and } R_{m 1} \text { is the } \\
\text { one day return for the market index } \\
\text { corresponding to the offering by the } \\
\text { firm } i \text {. }\end{array}$ \\
\hline $\begin{array}{l}\text { ZSCORE = Ex-ante } \\
\text { Financial Strength }\end{array}$ & - or + & $\begin{array}{l}\text { IPOs with high ex-ante financial strength } \\
\text { should be associated with lower ex-ante } \\
\text { uncertainty and as such, higher } \\
\text { performance. However, based on } \\
\text { overreaction hypothesis, high ex-ante } \\
\text { financial strength may be associated with } \\
\text { investors' over optimisms followed by } \\
\text { worse performance. }\end{array}$ & $\begin{array}{l}\text { An Altman Z-score is calculated } \\
\text { based on figures prior to the year of } \\
\text { listing to proxy the ex-ante financial } \\
\text { strength. }\end{array}$ \\
\hline $\begin{array}{l}\text { VOL= volume of } \\
\text { IPOs }\end{array}$ & - & $\begin{array}{l}\text { According to Ritter (1991), firms choose } \\
\text { to go public when investors are willing to } \\
\text { pay high multiples, reflecting optimistic } \\
\text { assessments. The negative aftermarket } \\
\text { performance then typically results due to } \\
\text { disappointing realizations of subsequent } \\
\text { net cash flows. }\end{array}$ & $\begin{array}{l}\text { VOLUME is equal to } \log (1+ \\
\text { number of IPOs in each year })\end{array}$ \\
\hline $\begin{array}{l}\text { INDUSTRY } \\
\text { DUMMY= Industry } \\
\text { effects }\end{array}$ & or - & $\begin{array}{l}\text { According to Ritter (1991), the wide } \\
\text { variation in the long run performance } \\
\text { and the underperformance in many } \\
\text { industries are being interpreted as being } \\
\text { consistent with the "fads" hypothesis. }\end{array}$ & $\begin{array}{l}\text { Following the principle used by } \\
\text { Allen et al. (1999), where similar } \\
\text { industries are grouped together, we } \\
\text { split the IPOs into two categories, } \\
\text { the non-financial sector and the other } \\
\text { sectors. This dummy variable takes } \\
\text { a value one if firms are in the non- } \\
\text { financial sector. }\end{array}$ \\
\hline $\begin{array}{l}\text { HOT }=\text { Dummy } \\
\text { Variable for the hot } \\
\text { issue periods }\end{array}$ & + & $\begin{array}{l}\text { According to Trautena, Schulz and } \\
\text { Dierkesc (2007), firms which go public } \\
\text { in hot markets tend to underperform } \\
\text { more than those going public in cold } \\
\text { markets. }\end{array}$ & $\begin{array}{l}\text { A dummy variable takes the value } \\
\text { one for firms which are listed during } \\
\text { the hot periods } 1989 \text { until } 1991 \text { and } \\
1993 / 1994 \text {, and zero otherwise. }\end{array}$ \\
\hline
\end{tabular}




\section{TABLE 4: Equally Weighted Average Initial Return by Sales of Firm}

Descriptive Statistics for average initial returns taking into account the percentage change from the offer price to the closing price on the first day of trading. The whole sample period consists of 44 newly listed Mauritian companies from 1989 to 2005. The periods 1989 though 1991 as well as 1993 until 1994 are considered the hot issue market while the rest of the sample is defined as the cold issue market. Sales are defined as annual turnover prior to going public. Given the small sample size, the sample is partitioned into two groups (low and high sales categories) based on the median value. Following the normality tests of all variables, the mean differences are tested using parametric and non-parametric tests. In our case, the Wilcoxon non-parametric test was applied only for the all issue category (where at least one variable was not normally distributed). p-values are reported in parentheses.

\begin{tabular}{|c|c|c|c|c|c|c|}
\hline \multirow[t]{2}{*}{ Sales Category } & 1989-2005 & Hot Issue & Cold Issue & Hot-Cold & Hot & Cold \\
\hline & \multicolumn{4}{|c|}{ Average Initial Returns (\%) } & \multicolumn{2}{|c|}{ Number of Issues } \\
\hline $\begin{array}{l}\text { LOW (< Rs } 210 \mathrm{M}) \\
\text { (p-values) }\end{array}$ & $\begin{array}{c}14.53 \\
(0.007)\end{array}$ & $\begin{array}{c}17.04 \\
(0.013)\end{array}$ & $\begin{array}{c}5.49 \\
(0.202)\end{array}$ & $\begin{array}{l}11.55 \\
(0.164)\end{array}$ & 18 & 5 \\
\hline $\begin{array}{l}\text { HIGH (> Rs } 210 \mathrm{M} \text { ) } \\
\text { (p-values) }\end{array}$ & $\begin{array}{c}10.09 \\
(0.000)\end{array}$ & $\begin{array}{l}11.15 \\
(0.010)\end{array}$ & $\begin{array}{c}7.98 \\
(0.066)\end{array}$ & $\begin{array}{c}3.17 \\
(0.457)\end{array}$ & 14 & 7 \\
\hline $\begin{array}{l}\text { ALL ISSUES } \\
\text { (p-values) }\end{array}$ & $\begin{array}{c}14.29 \\
(0.000)\end{array}$ & $\begin{array}{c}14.46 \\
(0.000)\end{array}$ & $\begin{array}{c}6.94 \\
(0.017)\end{array}$ & $\begin{array}{c}7.52 \\
(0.056)\end{array}$ & 32 & 12 \\
\hline
\end{tabular}

\section{TABLE 5: Average Initial Returns for Aftermarket Standard Deviation Categories}

The whole sample period consists of 44 newly listed Mauritian companies from 1989 to 2005. The periods 1989 though 1991 as well as 1993 until 1994 are considered the hot issue market while the rest of the sample is defined as the cold issue market. The aftermarket standard deviations have been calculated based on the first 20 daily returns in the aftermarket, excluding the initial returns. Given the small sample size, the sample is partitioned into two groups (low and high risk categories) based on the median value. Following the normality tests of all variables, the mean differences are tested using parametric and non-parametric tests. In our case, the Wilcoxon non-parametric test was applied only for the all issue category (where at least one variable was not normally distributed).

\begin{tabular}{|c|c|c|c|c|c|c|}
\hline \multirow[t]{2}{*}{ Risk Category } & 1989-2005 & $\begin{array}{l}\text { Hot } \\
\text { Issue }\end{array}$ & $\begin{array}{l}\text { Cold } \\
\text { Issue }\end{array}$ & Hot-Cold & Hot & Cold \\
\hline & \multicolumn{4}{|c|}{ Average Initial Returns (\%) } & \multicolumn{2}{|c|}{ Number of Issues } \\
\hline $\begin{array}{l}\text { LOW }(<0.03) \\
\text { (p-values) }\end{array}$ & $\begin{array}{c}7.04 \\
(0.001)\end{array}$ & $\begin{array}{c}8.70 \\
(0.010)\end{array}$ & $\begin{array}{c}4.63 \\
(0.050)\end{array}$ & $\begin{array}{c}4.07 \\
(0.476)\end{array}$ & 13 & 9 \\
\hline $\begin{array}{l}\text { HIGH (>0.03) } \\
\text { (p-values) }\end{array}$ & $\begin{array}{c}21.55 \\
(0.002)\end{array}$ & $\begin{array}{c}22.76 \\
(0.005) \\
\end{array}$ & $\begin{array}{c}13.89 \\
(0.199)\end{array}$ & $\begin{array}{c}8.87 \\
(1.000) \\
\end{array}$ & 19 & 3 \\
\hline $\begin{array}{l}\text { ALL ISSUES } \\
\text { (p-values) }\end{array}$ & $\begin{array}{c}14.29 \\
(0.000)\end{array}$ & $\begin{array}{c}14.46 \\
(0.000)\end{array}$ & $\begin{array}{c}6.94 \\
(0.017)\end{array}$ & $\begin{array}{c}7.52 \\
(0.056)\end{array}$ & 32 & 12 \\
\hline
\end{tabular}




\section{Table 6 Long Run Performance and Hot Issue Periods}

This table summarises the mean stock returns of post-listing three year buy-and-hold strategies for 44 Mauritian IPO companies from 1989-2005, categorised by hot/cold issues. With regards to hot/cold issues, the periods 1989 though 1991 as well as 1993 until 1994 are considered the hot issues while the rest of the sample is defined as the cold issue market. Buy-and-hold returns are equally weighted and measured from the close of the first day of listing until the three year anniversary of the IPO. BHR, SEMDEX BHR and BHAR refer to the mean raw, market and abnormal buy-and-hold returns, respectively. Wealth relatives are defined as one plus the mean three year total return on IPO companies divided by one plus the mean three year total return on market benchmark. All series are normally distributed according to the Kolmogorov-Smirnov test such that the parametric t-test is used.

\begin{tabular}{|l|c|c|c|c|c|c|}
\hline \multicolumn{6}{|l|}{ Long run performance of Hot and Cold IPOS } & \multicolumn{1}{l|}{} \\
\hline Types of Issues & $\begin{array}{l}\text { Number } \\
\text { of IPOs }\end{array}$ & $\begin{array}{l}\text { IPOs BHR } \\
(\%)\end{array}$ & $\begin{array}{l}\text { SEMDEX BHR } \\
(\%)\end{array}$ & BHAR (\%) & $\begin{array}{l}\text { Wealth } \\
\text { Relative }\end{array}$ & $\begin{array}{l}\text { BHAR: HOT-COLD } \\
\text { Paired-Samples T test } \\
\text { (p-values in parentheses) }\end{array}$ \\
\hline $\begin{array}{l}\text { Hot Issues } \\
(1989-1991)\end{array}$ & 19 & 1.10 & 1.62 & -0.52 & 0.9949 & 0.57 \\
\hline $\begin{array}{l}\text { Hot Issues } \\
(1993-1994)\end{array}$ & 13 & -0.45 & 0.31 & -0.76 & 0.9925 & $(0.52)$ \\
\hline Hot Issues (All) & 32 & 0.47 & 1.09 & -0.62 & 0.9939 & $(0.68)$ \\
\hline Cold Issues & 12 & -0.10 & 0.90 & -1.00 & 0.9901 & $(0.57$ \\
\hline
\end{tabular}

Table 7 Return Variance in Hot and Cold Issue Periods

This table summarises the mean stock returns of post-listing 12 month buy-and-hold strategies for 44 Mauritian IPO companies from 1989-2005, categorised by hot/cold issues. With regards to hot/cold issues, the period 1989 though 1991 as well as 1993 until 1994 are considered the hot issues while the rest of the sample is defined as the cold issue market. Buy-and-hold returns are equally weighted and measured from the close of the first day of listing until the 12 month anniversary of the IPO. RETVAR refer to the 12-month buy and hold abnormal return variances. All series are normally distributed as per the Kolmogorov-Smirnov test such that the parametric t-test is used.

\begin{tabular}{|l|c|c|c|}
\hline Long run performance of Hot and Cold IPOs & \multicolumn{2}{|c|}{$\begin{array}{l}\text { RETVAR: HOT-COLD } \\
\text { Non-Parametric test } \\
\text { (P-values in parentheses) }\end{array}$} \\
\hline Types of Issues & Number of IPOs & RETVA (\%) & $\begin{array}{c}-2.784 \\
(0.072)\end{array}$ \\
\hline Hot Issues (1989-1991) & 19 & 0.5521 & $\begin{array}{c}-2.947 \\
(0.057)\end{array}$ \\
\hline Hot Issues (1993-1994) & 13 & 0.8960 & -3.255 \\
$(0.039)$
\end{tabular}




\section{TABLE 8: Factors Influencing the Likelihood of IPOs during Hot and Cold Phases}

The sample period takes into account 44 IPOs from 1989 until 2005. The dependent variable, HOT, is equal to 1 when a particular company goes public in a hot phase or 0 if the company goes public in a cold phase. The independent variables are defined as follows: MAAR = Short-Run Underpricing, MARKET= Market performance prior to the issue, INDUSTRY = Industry Clustering Dummy, RISK= Aftermarket risk level of the IPO, SALES= prior listing Annual Turnover of the firm, BHAR= Long Run Performance of IPOs and RETVAR $=$ Cross section variance of IPO returns.

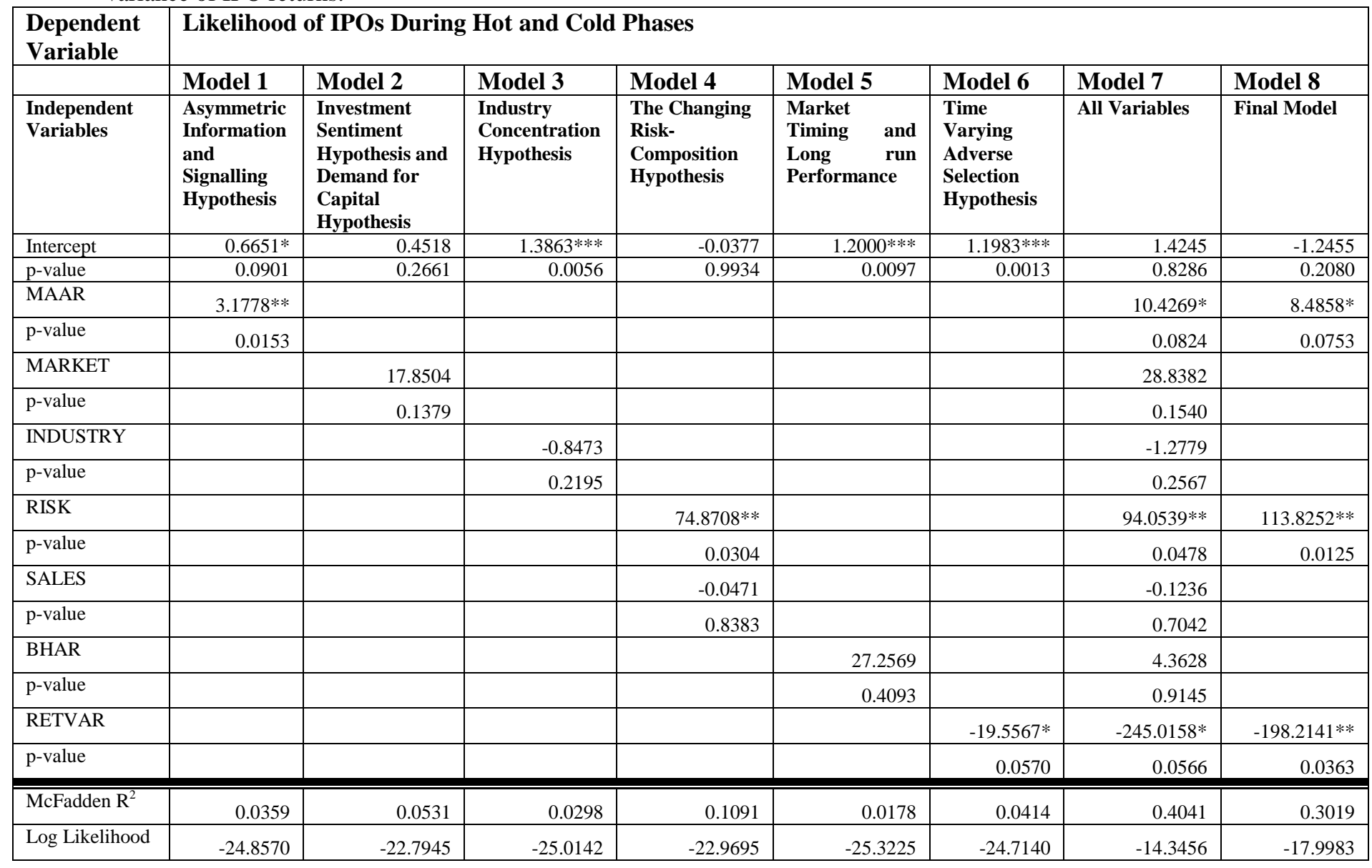




\section{TABLE 9: Short Run Underpricing and the Hot Issue Period}

The sample period takes into account 44 IPOs from 1989 until 2005. The dependent variable is the initial raw and market adjusted returns of companies where as the independent variables are defined as follows: RISK= Aftermarket risk level of the IPO, ZSCORE= Altman's Z-score prior to listing, BROKREP = Stock broker's reputation, AUDITREP $=$ Auditor's Reputation, and HOT=dummy variable taking one for firms which are listed during the period 1989 until 1991 and 1993/1994. White's (1980) adjusted student t-statistics are used where appropriate with the p-values reported below each estimate.

\begin{tabular}{|l|r|r|r|r|}
\hline $\begin{array}{l}\text { Dependent } \\
\text { Variable }\end{array}$ & \multicolumn{2}{|c|}{ Initial raw returns } & \multicolumn{2}{c|}{ Initial Market Adjusted Returns } \\
\hline & Model 1 & Model 2 & Model 3 & Model 4 \\
\hline Variables & Bivariate Analysis & All Variables & Bivariate Analysis & All Variables \\
\hline Intercept & $0.0694^{* * *}$ & -0.0753 & $0.0684^{* * *}$ & 0.0757 \\
\hline p-value & 0.0064 & 0.4190 & & 0.4112 \\
\hline RISK & & $7.7363^{*}$ & & $0.7942^{* *}$ \\
\hline p-value & & 0.0688 & & -0.0124 \\
\hline ZSCORE & & $-0.0043^{* *}$ & & $0.0041^{* *}$ \\
\hline p-value & & 0.0150 & & -0.0334 \\
\hline BROKREP & & -0.0533 & & 0.6705 \\
\hline p-value & & 0.4882 & & $0.1290^{* *}$ \\
\hline AUDITREP & & $0.1213^{* *}$ & & 0.0157 \\
\hline p-value & $0.1010^{* *}$ & 0.0213 & & -0.0098 \\
\hline HOT & 0.0567 & -0.0036 & $0.0865^{*}$ & 0.7945 \\
\hline p-value & 0.0177 & 0.9262 & 0.0980 & 0.1280 \\
\hline \hline Adjusted R & 1.7768 & 0.1525 & 0.0072 & 2.2629 \\
\hline F-VALUE & 0.1897 & 2.5472 & 0.3126 & 0.0677 \\
\hline Prob.(F) & 0.2921 & 0.0440 & 0.2584 & \\
\hline $\begin{array}{l}\text { White's (1980) } \\
\text { Heteroscedasticity } \\
\text { Test- (P-value) }\end{array}$ & & & 0.2735 & \\
\hline
\end{tabular}


TABLE10: Long Run Performance and the Hot Issue Period

The sample period takes into account 44 IPOs from 1989 until 2005. The dependent variable is the three-year buy and hold abnormal returns of companies and the independent variables are defined as follows: MAAR $=$ Short-Run Underpricing, ZSCORE= Altman's Z-score prior to listing, VOL= volume of IPOs, , INDUM= Industry effects, and HOT=dummy variable taking one for firms which are listed during the period 1989 until 1991 and 1993/1994. White's (1980) adjusted student t-statistics are used where appropriate with the p-values reported below each estimate.

\begin{tabular}{|l|r|r|}
\hline & Buy and Hold Abnormal Returns & Model 2 \\
\hline Dependent Variable & Model 1 & All Variables \\
\hline Variables & Bivariate Analysis & $-0.0225^{* *}$ \\
\hline Intercept & $-0.0100^{* * *}$ & 0.0399 \\
\hline p-value & 0.0061 & -0.0075 \\
\hline MAAR & & 0.3555 \\
\hline p-value & & $-0.0004^{* *}$ \\
\hline ZSCORE & & 0.0333 \\
\hline p-value & & 0.0314 \\
\hline VOL & & 0.1256 \\
\hline p-value & & 0.0007 \\
\hline INDUM & & 0.8404 \\
\hline p-value & & -0.0093 \\
\hline HOT & 0.0039 & 0.3008 \\
\hline p-value & 0.3470 & 0.0828 \\
\hline \hline Adjusted R & & 1.7759 \\
\hline F-VALUE & 0.0211 & 0.1412 \\
\hline Prob.(F) & 0.9047 & 0.1017 \\
\hline $\begin{array}{l}\text { White's (1980) Heteroscedasticity } \\
\text { (p-value) }\end{array}$ & 0.3470 & 0.1371 \\
\hline
\end{tabular}

